\title{
BETWEEN MIGHTY HILLFORTS: A MULTI-METHOD STUDY OF LAUKSKOLA BRONZE AGE SETTLEMENT POTTERY
}

\author{
VANDA VISOCKA,,$^{1,2^{*}}$ ALISE GUNNARSSONE, ${ }^{2}$ MĀRCIS KALNIN̦Š, ${ }^{1}$ \\ EDUARDS PLANKĀJS ${ }^{2,3}$
}

\author{
${ }^{1}$ University of Latvia Faculty of History and Philosophy, Department of History and Archaeology, Aspazijas Blvd 5, Riga, Latvia \\ ${ }^{2}$ National History Museum of Latvia, Department of Archaeology, Pulka St 8, Riga, Latvia \\ ${ }^{3}$ University of Latvia Institute of Latvian History, Kalpaka Blvd 4, Riga, Latvia
}

\section{Keywords}

Lower Daugava, Late Bronze Age, pottery, petrography, WD-XRF, survey of clays, reflective transformation imaging

\begin{abstract}
This paper presents the results of a multi-method study of the Laukskola Late Bronze Age open field settlement pottery assemblage. The aim of the study was to describe the technical and stylistic aspects of Laukskola pottery, and their relationship with the nearby hillfort material. The production tendencies and their role in the function of the pottery were also analysed. Macroscopic analysis combined with ceramic petrography, reflective transformation imaging, and wavelength dispersive X-ray fluorescence spectroscopy were conducted in the analysis of the pottery. Nearby clay resources were surveyed and further analysed for provenance interpretations. The results of the study show that Laukskola pottery was locally produced by using highly plastic sandy moraine clay, tempered with granitic rock and quartzite. Stylistically, the pottery combined local and nonlocal elements. The function corresponds with the visual parameters and choices for production.
\end{abstract}

\section{Introduction}

Laukskola archaeological complex, which includes several objects, is located on the right bank of the Lower Daugava, in the parish of Salaspils, between the Budeskalni farm and school, facing Daugmale hillfort, which is on the left bank of the Daugava (Zarina 2006, p. 9) (Fig. 1). Due to the construction of the Riga Hydroelectric Power Station, Laukskola was excavated between 1967 and 1975, led by the archaeologist Anna Zarina, and is now underwater (Zarina 1968; 1969; 1970a; 1971; 1972; 1973; 1974; 1975a; 1976). Two main chronological horizons were uncovered at Laukskola: the Palaeolithic and Late Iron Age settlement, and the burial ground of the Livs. However, archaeological reports also show traces of habitation during the Late Bronze Age (LBA) as well (Zarina 1975b, p. 181).

Laukskola archaeological complex is best known for the Palaeolithic settlement and Late Iron Age burial ground, both of which have been studied in great detail (see Zagorska 1994; 2012; Zarina 2006). Much less attention has been paid to the Bronze Age finds, i.e., the pottery found in the area. At least 11 reconstructable vessels and numerous sherds attributable to the Late Bronze Age were found in different features during the excavations (Šulte and Gunnarsson 2017; Vasks 1991). Although the amount of vessels indicates habitation, it is impossible to determine whether this was a long-term or a short-term settlement. It is the only settlement in the Lower Daugava with a comparably large amount of pottery in such good condition, making it possible to determine the production tendencies and to compare it to ceramic assemblages from hillforts.

The aim of this study is to determine the pottery production and its stylistic tendencies in the Laukskola settlement against the background of ceramic assemblages from nearby LBA hillforts: Klan,gukalns, Kivutkalns and

*Corresponding author. E-mail: vanda.visocka@lu.lv 


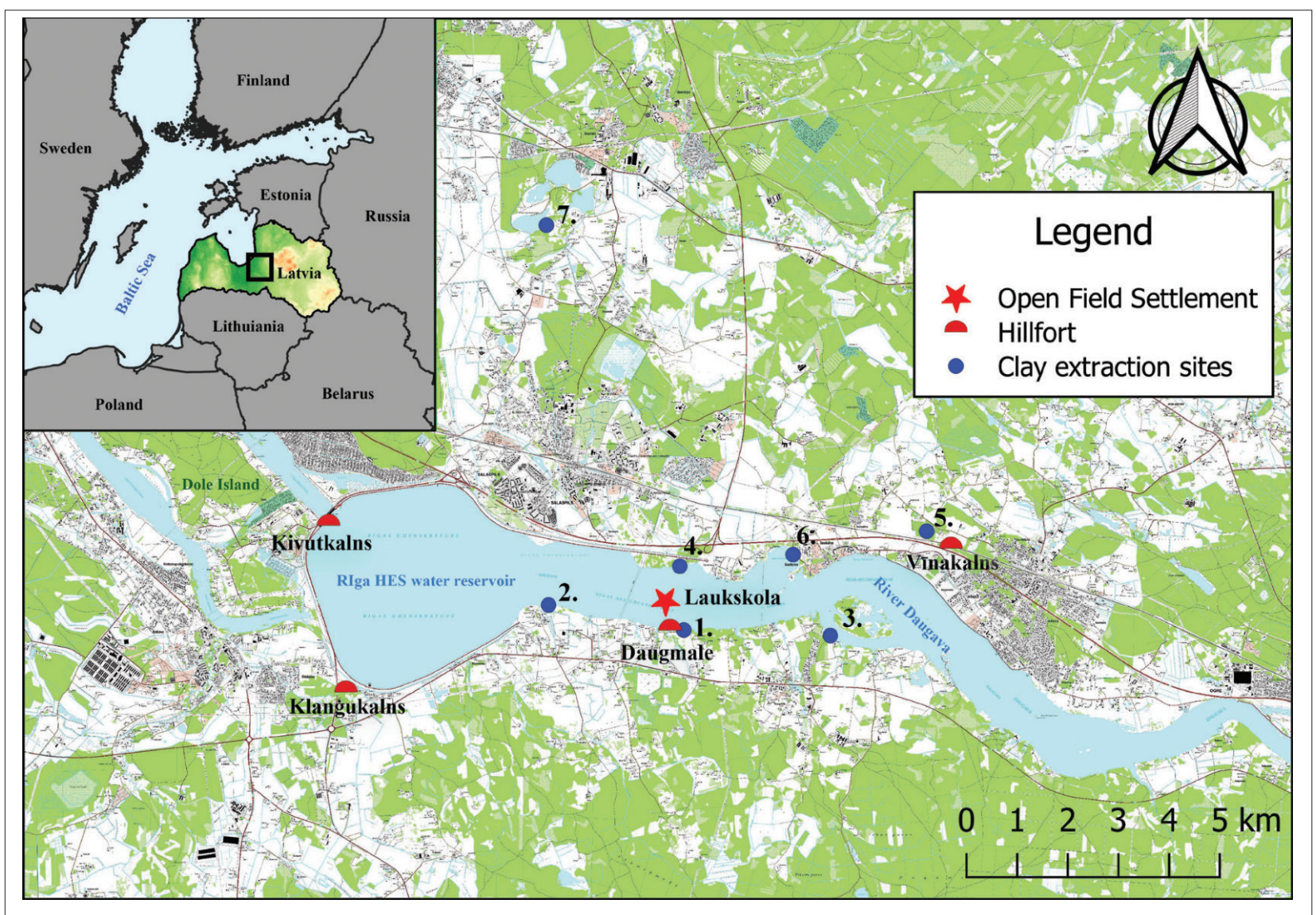

Figure 1. The location of the settlements mentioned in this study, and the clays sampled: 1. DGM 1, 2; 2. DZI 1, 2; 3. NAS1; 4. SAL2; 5. SLD 1, 2; 6. SLKL1; 7. SRS1(Basemap: Topokarte M1:10000, LGIA. LU ĢZZF WMS. View: 30.06.2021. Available from: http:// kartes.geo.lu.lv/, author: M. Kalniņš).

Vīnakalns. In order to achieve this aim, multiple research methods were used:

1. Macroscopic analysis: the classification of characteristics of the pottery's visual features, morphology, and use-wear patterns - soot crust.

2. Reflective transformation imaging (RTI), in order to study the surface texture and the application of surface treatments. RTI models were made according to guidelines published by Cultural Heritage Imaging (Mudge et al. 2013). Approximately 55 photographs from angles of $15^{\circ}$ to $75^{\circ}$ around the hemisphere, with additional specific angles, were made of each sample, with the distance of the light source at 50 centimetres. Models were made of two vessels.

3. Survey of nearby clays: distinguishing the availability of the resource and its properties in order to interpret provenance. The right and left banks of the River Daugava within a radius of about ten kilometres around Laukskola were surveyed, and 11 samples overall were collected. In order to compare the clay resources with the pottery, clay briquettes were made: the clay was airdried and ground afterwards, and impurities such as large pebbles and weeds were removed manually. The clay powder was mixed with distilled water until flexible enough to shape it into a cube, and air-dried. Lastly, the samples were fired at $700^{\circ} \mathrm{C}$, which is considered to be the maximum achievable firing temperature for the pit firing technique (Visocka et al. 2021; Dumpe et al. 2016). This allowed for a comparison to be made between the sampled clay and the analysed pottery, as similar chemical and mineralogical reactions took place in both sets.

4. Ceramic petrography, by using a thin sectioning method, was used to determine the tempering tendencies and paste recipes of the pottery, and to compare them to the mineralogical properties of the clay briquettes (for a detailed description of the preparation, see Quinn 2013). Overall, two pottery samples, one from a reconstructable vessel with impressed ornamentation (Table 1, No. 2), and one striated sherd, and five clay samples were analysed by this method.

5. Wavelength dispersive $\mathrm{X}$-ray fluorescence analysis was used to determine and compare the chemical composition of the clays and the pottery. A non-destructive approach was used. Elements in their oxide form were measured in the Helium atmosphere, the size of the 


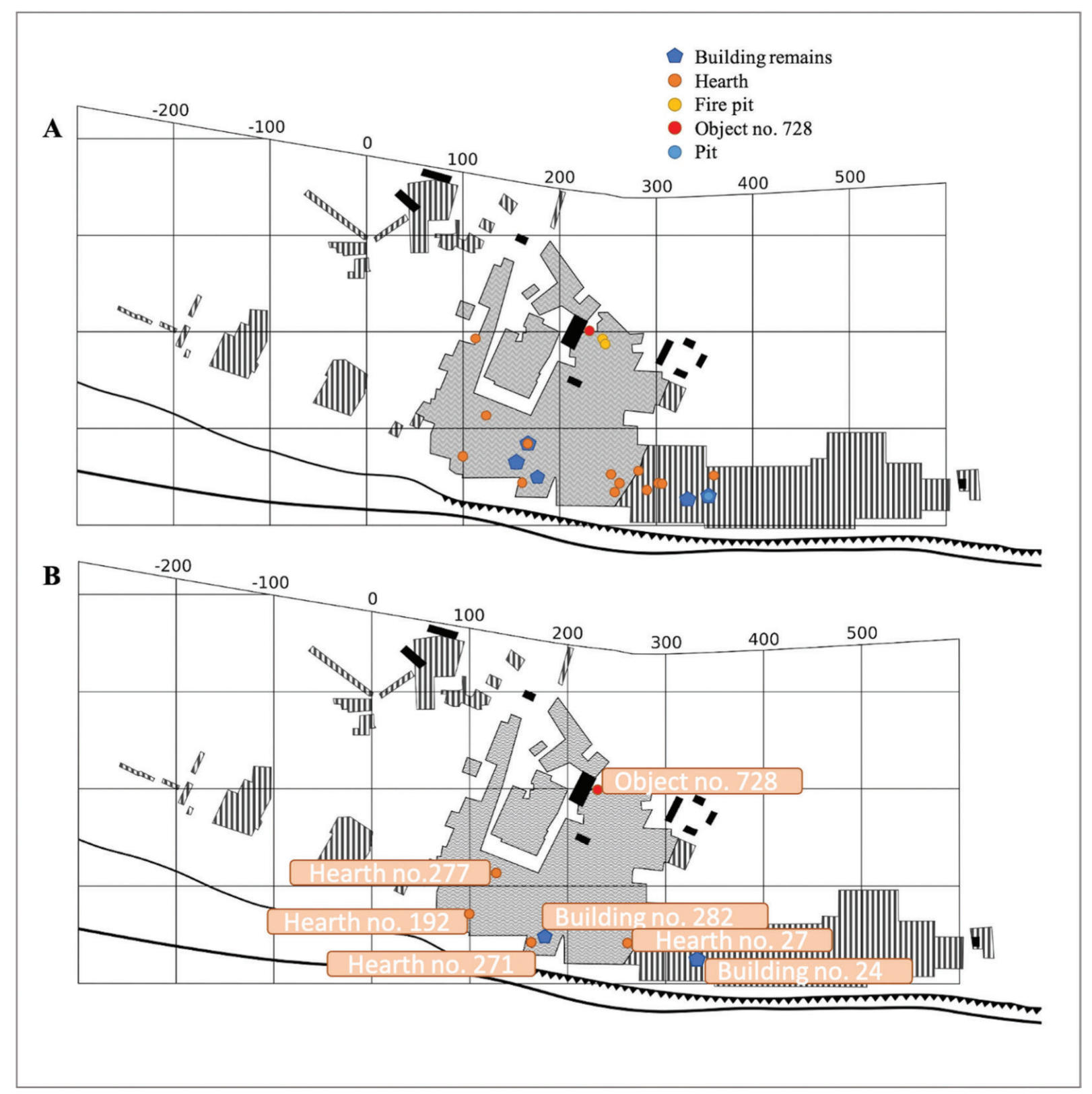

Figure 2. A plan of the excavation area. The striped area represents the settlement; the chevron the cemetery; the modern buildings are in solid black (A. objects with finds of striated pottery; B. objects containing solely LBA pottery; plan prepared by A. Gunnarssone).

irradiation area of the sample holder was eight millimetres. Three measurements of each sample were taken, from which the average concentration of elements was calculated. The same two pottery samples from Laukskola settlement, three from Vīnakalns, and five sherds from Klanginualns hillfort, as well as ten clay briquettes, were analysed. Principal component analysis (PCA) was used to group and analyse the data obtained.

14C AMS radiocarbon analysis was also performed on the food crust from one of the vessels to clarify the chronology of the settlement, as well as some experimental work regarding the ornamentation of the vessels.
As object No 728 contained the best-preserved vessels, most attention in this article is paid to the pottery from this feature.

\section{Spatial distribution and chronology}

In the ten hectares of the Laukskola site complex that were excavated (Vasks 2021, p. 112), 728 of the surveyed features contained ceramic sherds. As the site has multiple layers of habitation, it was possible to encounter cases where earlier features were contaminated by later additions, and also situations where features made later had 


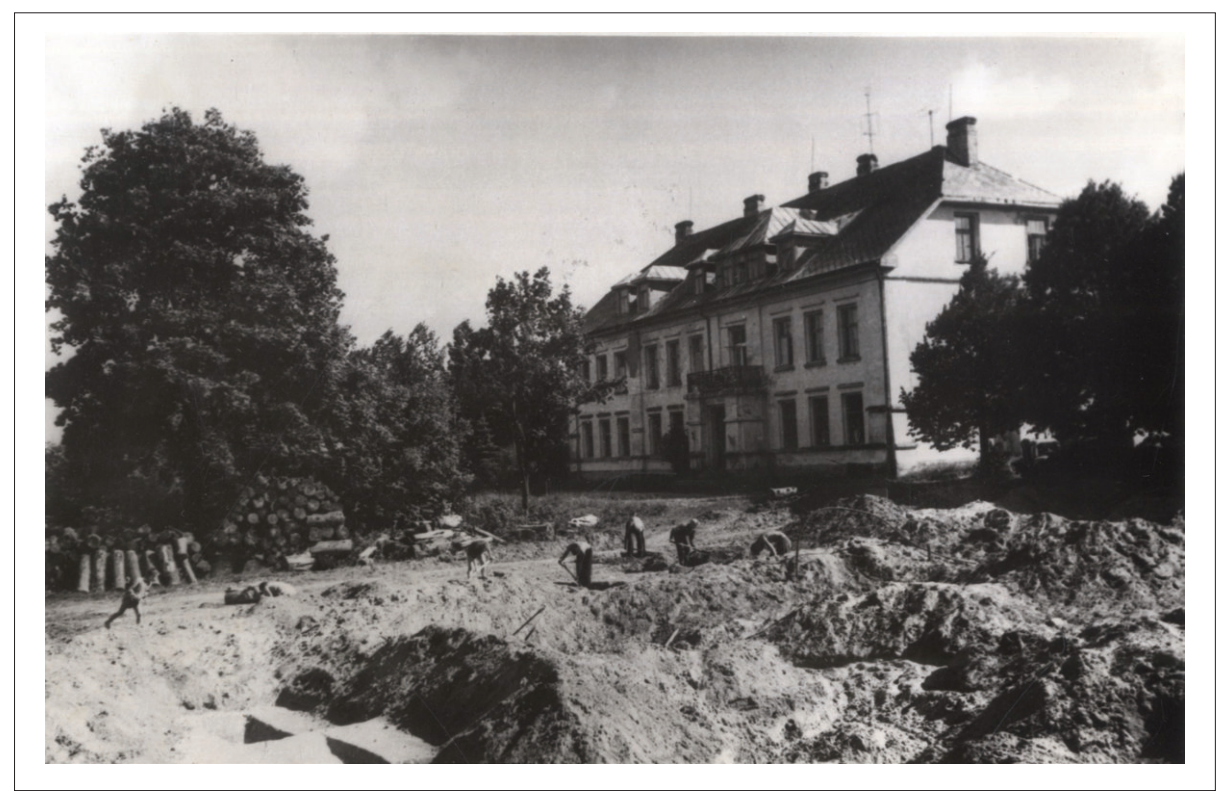

Figure 3. The scene of the excavation near the school building (after Zarina 1970b, Fig. 3).

incorporated sherds from earlier periods. Of the excavated features, 20 included finds of striated pottery (Fig. 2.A), and of those, only seven features did not contain any ceramics from the Late Iron Age settlement (Fig. 2.B).

Most of the finds of striated pottery were located along the banks of the Daugava, with two distinct regions of concentration (following X axis: 150-170 and 280-350) (Šulte and Gunnarsson 2017, p. 12). However, the most notable LBA feature was located some distance from this region: 199-200 x 228-231 (Fig. 2). The two geographically closest features to it (with LBA pottery) were both cremation burials attributed to the Late Iron Age, where striated pottery was only an accidental contamination. It is possible that there might have been more LBA features to the west of feature No 728, as they would not have been found due to a modern construction in this location (Fig. 3). Even feature No 728 was already partly destroyed by modern construction digging (Zarina 1975b, p. 181).

Feature No 728 contained in total 184 sherds of striated pottery, and one sherd of striated-coarse-slipped pottery. As a comparison, this was five times more sherds of striated pottery than the next-largest LBA feature. Most of the sherds were stylistically variable, and in surprisingly good condition.

In the excavation reports, feature No 728 was characterised as a hearth. Although the coordinates given for it were 199-200 x 228-231, it is mentioned in the description that it took up a much larger area of dark soil $(20 \mathrm{x}$ 2-4 m) (Zariņa 1975b, p. 181). It consisted of dark soil mixed with medium-sized burnt and crushed rocks, and ceramic sherds were located throughout all the dark soil.
Similar descriptions were given of features No 281 and No 282. Both were larger than the hearths around them, reaching ten by nine and nine by two metres (Zarina 1970b, Fig. 1). Both consisted of dark soil with burnt and crushed rocks. These features were characterised in the descriptions as the remains of buildings. They also contained several hearths (Zarina 1975b, pp. 194-197). It is possible that feature No 728 was a hearth located inside a building that had been partly destroyed in the modern construction, or it could have been another kind of feature altogether, such as a household pit. Regrettably, there are no drawings, and no photographs of the feature itself, to clarify this question.

According to the 14C AMS analysis of food crusts from the striated pottery, the chronology of object No 728, and presumably the settlement, is 791-544 cal BC (2525 \pm $30 \mathrm{BP}$ ), i.e. the end of the LBA. During this period, the nearby hillforts at Klangukalns (ca. $1100 \mathrm{BC}$ to 2nd century AD), Kivutkalns (ca. $650 \mathrm{cal} \mathrm{BC}$ to 2nd century AD), and Vinakalns (772-476 BC [2480 \pm 30 BP], 786-541 BC $[2510 \pm 30 \mathrm{BP}]$ and $789-544 \mathrm{BC}[2520 \pm 30 \mathrm{BP}])$ were inhabited (Šnore 1936, pp. 61-62; Vasks and Zariņa 2014, p. 29). The similar habitation chronology between Laukskola open field settlement and Vīnakalns hillfort is especially notable.

\section{Clays in the Lower Daugava and LBA pottery}

The most common minerals in the Lower Daugava are Devonian dolomite and gypsum; there are no quaternary clay deposits found in this area. The only known and studied clay deposit in the Lower Daugava is the Devonian 
clay (marl clay) deposit of Dole Island. At the end of the 1940s, due to the construction plans for Riga Hydroelectric Power Station, several geological surveys and studies were carried out in Dole Island. Detailed attention was given to the marl clays that were used to make stove tiles (Skrastinsh 1948). Chemical analysis showed relatively low $\mathrm{SiO} 2$ (28.29\%) and very high $\mathrm{CaO}$ and $\mathrm{MgO}$ (20.49\%, $14.18 \%$ ) concentrations, which is typical of marl clays (Skrastinsh 1948, pp. 52-53). Overall, the Devonian clay of Dole Island is medium-plastic, due to the large concentration of carbonates (Kuršs and Stinkule 1972, p. 43). Therefore, it is not very likely to have been used (or used solely) in the production of prehistoric pottery, due to the high possibility of breakage during the firing process (Eriksson and Lindahl 2012, p. 47).

In order to determine the main characteristics and availability of the clays, both banks of the Daugava were surveyed in a roughly ten-kilometre radius of the Laukskola settlement (see Fig. 1). Ten samples were collected from seven areas (Table 2). One clay sample (SRS1) was taken from the Saurieši gypsum deposit, where blue clays and dolomite grains are characteristic impurities (Eiduks 1961, p. 351). This sample was chosen as the statistical point for petrographic and chemical analysis, as the authors are sure that this clay was not used in the production of pottery, for it is full of sharp gypsum needles, and was located on the lower level of the dug area (ca. $15 \mathrm{~m}$ ). All the samples collected (except SRS1) were malleable reddish or reddish-brown moraine clay, containing mainly small grains from feldspars, quartz and pebbles. Notably, in one case (SLKL1), the River Daugava had purified the clay (violet-brown, very plastic), making it clean with no impurities. Overall, moraine clays suitable for pottery production were easily obtainable, and were found either on the bank (DZI, DGM1, NAS1, SLKL) of the river or just under the turf (DGM2, SLD).

The results of WD-XRF analysis show that most of the clays are high in $\mathrm{SiO} 2$ (conc. 57.07\%-71.29\%) and $\mathrm{Al} 2 \mathrm{O} 3$ (11.29\%-16.88\%), while $\mathrm{Fe} 2 \mathrm{O} 3$ and $\mathrm{K} 2 \mathrm{O}$ are in similar concentrations $(3.25 \%-5.38 \%$ and $3.9 \%-5.59 \%)$. Notably, most samples with lower $\mathrm{SiO} 2(38.66 \%-52.37 \%)$ had much higher $\mathrm{MgO}$ and $\mathrm{CaO}$ concentrations (Table 3). Clays with higher aluminium and alkali metal oxides, and less silica oxides, are considered to be fatty, and therefore highly plastic; in turn, clays with a higher calcium and magnesium oxide concentration are lean, and relatively unmalleable (Kuršs and Stinkule 1972, p. 65; Andrade et al. 2011, p. 1). The chemical composition of the pottery samples shows that the potters used very plastic clay, with high $\mathrm{SiO} 2(51.35 \%-65.66 \%)$, and $\mathrm{Al} 2 \mathrm{O} 3$ and $\mathrm{Fe} 2 \mathrm{O} 3$ (11.16\%-19.45\%), and with far less $\mathrm{CaO}(0.56 \%-9.94 \%)$ and $\mathrm{MgO}(1.19 \%-2.64 \%)$ concentrations (Table 3).
PCA graphs from the chemical data of the clay and pottery samples were made. Overall, four PCA graphs were created, with different element combinations: all elements detected, major, minor and rare, and lastly selected elements (Fig. 4.1-4). The last, selected element, graph was made using major elements, excluding those which might have been influenced by post-depositional alteration, Ca, Mn and P (Hall 2016, p. 347), and elements whose concentration, at least in one of the samples, is higher than $0.09 \%$. As predicted, Saurieši gypsum clay, in all the variations, does not correspond to any pottery samples, or even most of the clays, except for the Saulkalne (SLKL1) sample, where they are similar in all elements (Fig. 4.1) and major element (Fig. 4.2) graphs. It can be seen that, overall, chemically, the clays do not correspond to pottery, as according to graphs Nos 1, 2 and 4, a few Kivutkalns samples, which might have had a similar composition to Daugmale (DGM), Saulesdārzs (SLD) and Dzintari (DZI) clays, can be considered an exception. The Laukskola samples, in all the cases, correspond to each other, as well as to the nearby hillfort pottery, and thus were most likely made locally.

The results of the petrographic analysis of clay thin sections show that four samples (DGM1, 2, DZI2 and SLD2) are coarse, and abundant with grains of silt and sand (Fig. 5). Quartz grains and some small accessory minerals are distinguishable as well. In the DZI2 sample, some carbonaceous grains (possibly dolomite) can be seen, which corresponds with the chemical analysis where in this sample $\mathrm{CaO}$ is very abundant. Coarse clay with abundant mineral and rock impurities are characteristic of moraine clay. As was predicted, in the SRS1 sample, the clay is high in gypsum (GP) impurities, mica is common as well, and sand less. The results show that Laukskola pottery was made using very similar coarse (moraine) clay. DZI2 and SRS1, abundant with carbonaceous minerals, should be considered an exception. Such clay was not distinguished in the Laukskola samples.

\section{Tendencies in pottery production}

Clay matrix. Both the Laukskola settlement pottery thin section samples showed that they were made with coarse clay, rich in coarse and fine sand, and mica is common in both sherds (Fig. 6). In the clay of the LK1 sample, iron oxide compounds were distinguished. The clay was tempered with crushed granitic rock, indicated by plagioclase feldspar, quartz and mica; the added volume in the paste was $4.1 \%$. The temper is medium coarse (the largest grain $2 \mathrm{~mm}$, the maximum average $1.5 \mathrm{~mm}$ ), and homogenous, which indicates that it might have been sieved or carefully sorted before adding to the paste; whereas LK2 was tempered with crushed quartzite rock grain, indicated by the quartz grains densely fused together (Fig. 7.A, B). 


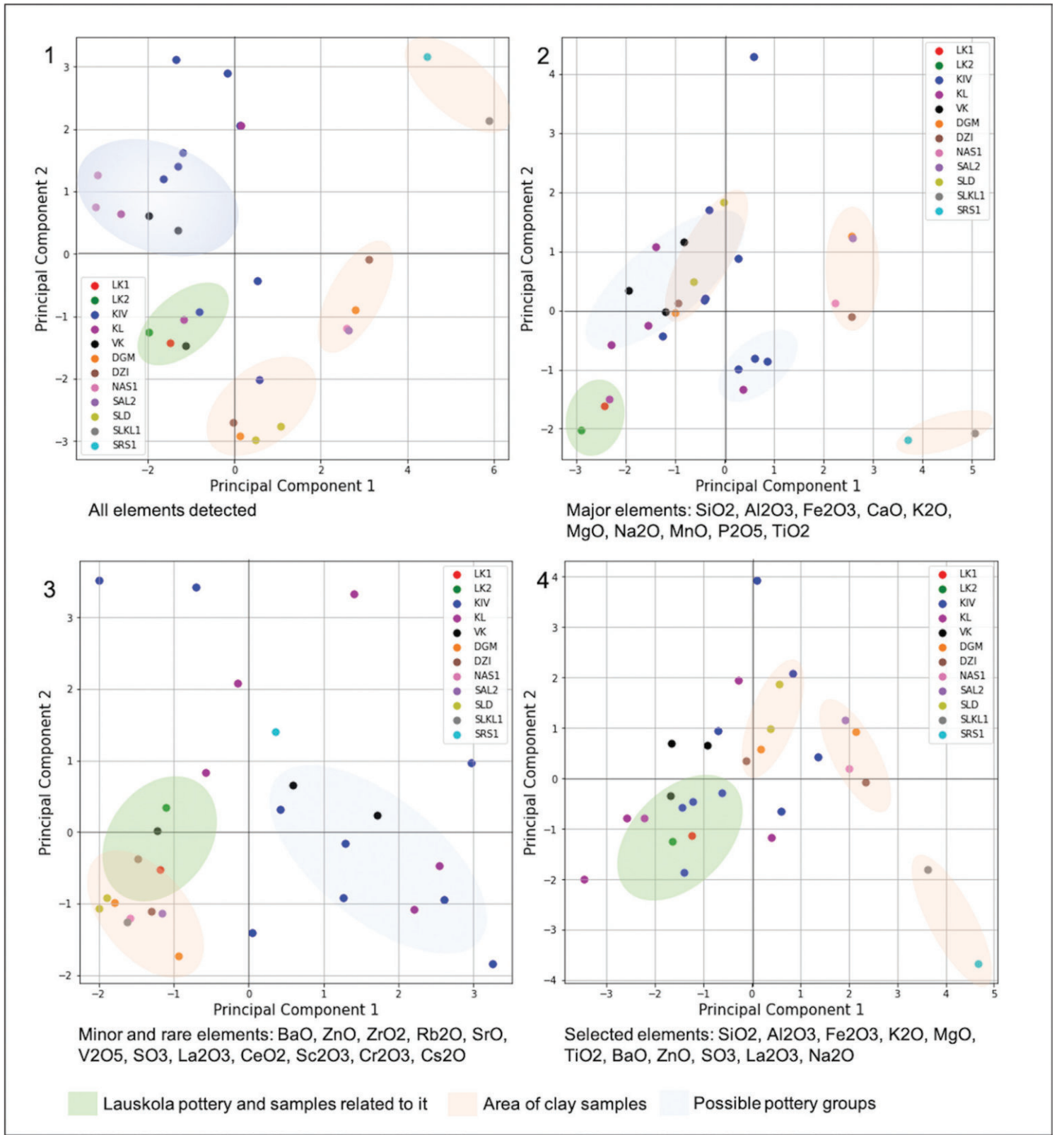

Figure 4. PCA graphs from the chemical composition of the pottery and clay samples: 1. with all detected elements included; 2. with only the main elements as variables; 3 . only minor and rare elements; 4 . a selection of the elements (prepared by Visocka with Python in Google colaboratory notebook. Available from: https://colab.research.google.com/).

A few grains, such as quartz, feldspar and mica, indicate that rock temper was used as well, in addition to the quartzite granitic rock (Fig. 7.C, D). The added volume of the temper is $15.6 \%$. The temper is medium coarse (the largest grain $3.2 \mathrm{~mm}$, the maximum average $2.74 \mathrm{~mm}$ ), and with medium homogeneity. Macroscopically determined, the largest grain sizes of the Laukskola vessels varied from three to $6.5 \mathrm{~mm}$, medium coarse to coarse.

Comparing the clay matrix tendencies between Laukskola and hillfort material (Klangigukalns, Kivutkalns and Vīnakalns), quite clear similarities can be seen. First of all, most of the pottery was made using sandy coarse (moraine) clay; only on a few occasions was fine (possibly purified) clay used. The main tendencies in temper- ing (volume and size) vary slightly between hillforts: at Klangukalns, volume $10 \%$ to $30 \%$, the largest grain 3.3 to 6.3 millimetres; Kivutkalns $8 \%$ to $32 \%$, two to six millimetres; Vīnakalns $6 \%$ to $20 \%, 2.5$ to six millimetres (Visocka 2020, pp. 101-103; Visocka et al. forthcoming, Table 1; Visocka 2017a, p. 9). In all the cases in the Lower Daugava, crushed granitic rock was used as a tempering material in the LBA; the authors of this paper know of no analogies of quartzite being used as a temper. However, quartzite rock is common in Latvia, mainly in the form of small boulder stones, and it was used as a tool, mainly as a whetstone, during the Iron Age (Sedmalis and Šperberga 2005, p. 62). Thus, it cannot be interpreted purely as an imported material or pottery. 

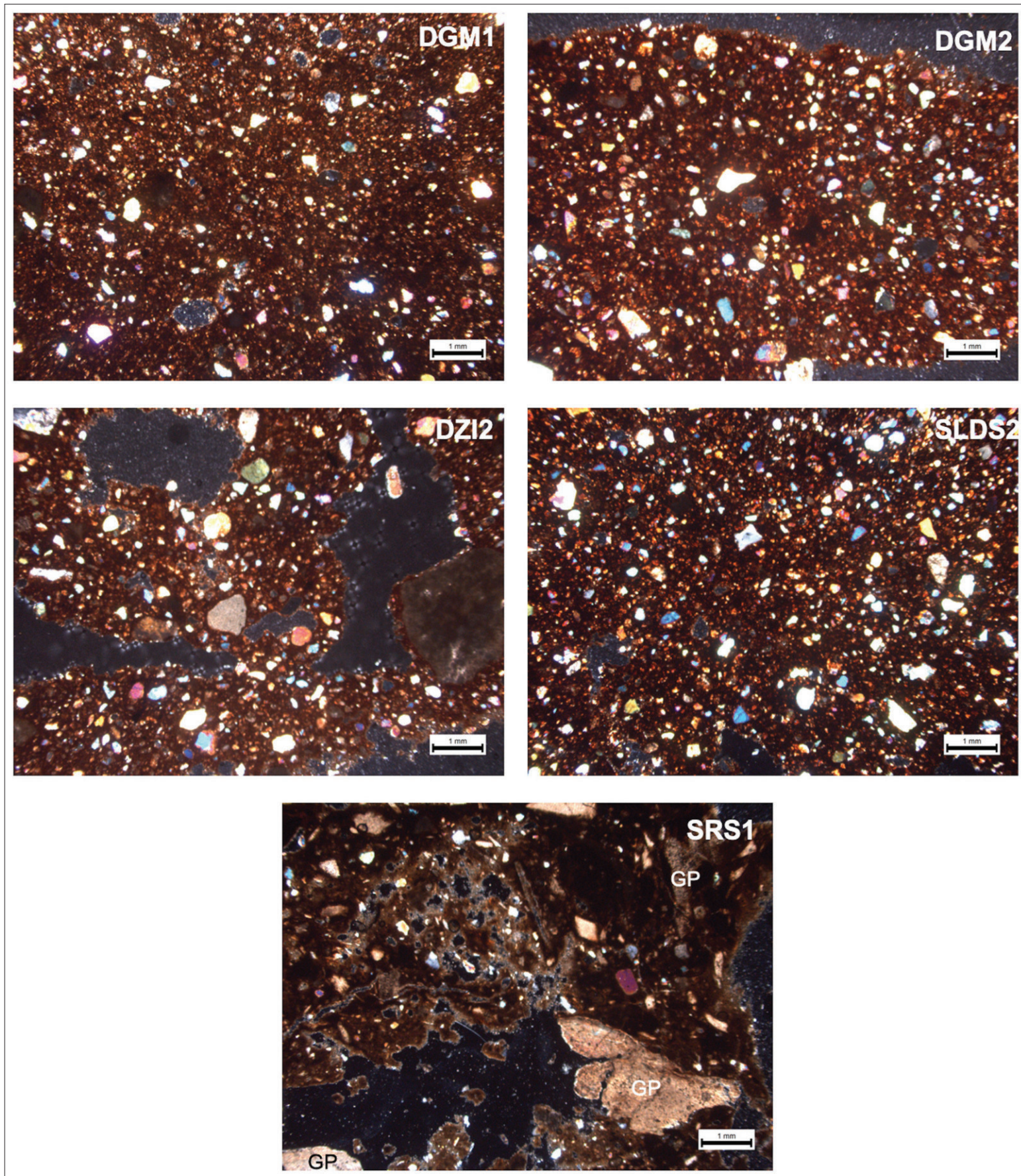

Figure 5. Micrographs of clay thin sections (XPL, GP gypsum; prepared by V. Visocka).

On two pottery sherds, seed imprints were distinguished on the inner surfaces (Fig. 8). Based on the shape (from the imprint and clay positive), the first seed could be identified as wheat (triticum), but the identity of the other seed is not clear. This indicates that the pottery was made in a long-term settlement where farming was practised. Farming was quite common in the LBA in the Lower Daugava area, which is indicated not only by grindstones, but also by the rich charred seed material discovered at Kivutkalns hillfort (Rasinš and Taurina 1983). As has been mentioned, it is impossible to determine the settlement habita- tion type (short-term, long-term); therefore, it is not clear if pots were made at the Laukskola settlement or not.

Forming techniques. The coiling technique was used in order to build a ceramic vessel in the LBA. From all the 11 reconstructable vessels from object No 728, it was possible to determine the coiling types of four samples (Table 1). Three of the vessels were made using the ' $U$ ' and one by using the ' $\mathrm{N}$ ' coil pressing technique. This does not mean that one way was more common than another. It is impossible to tell from the statistics, due to the small number of 

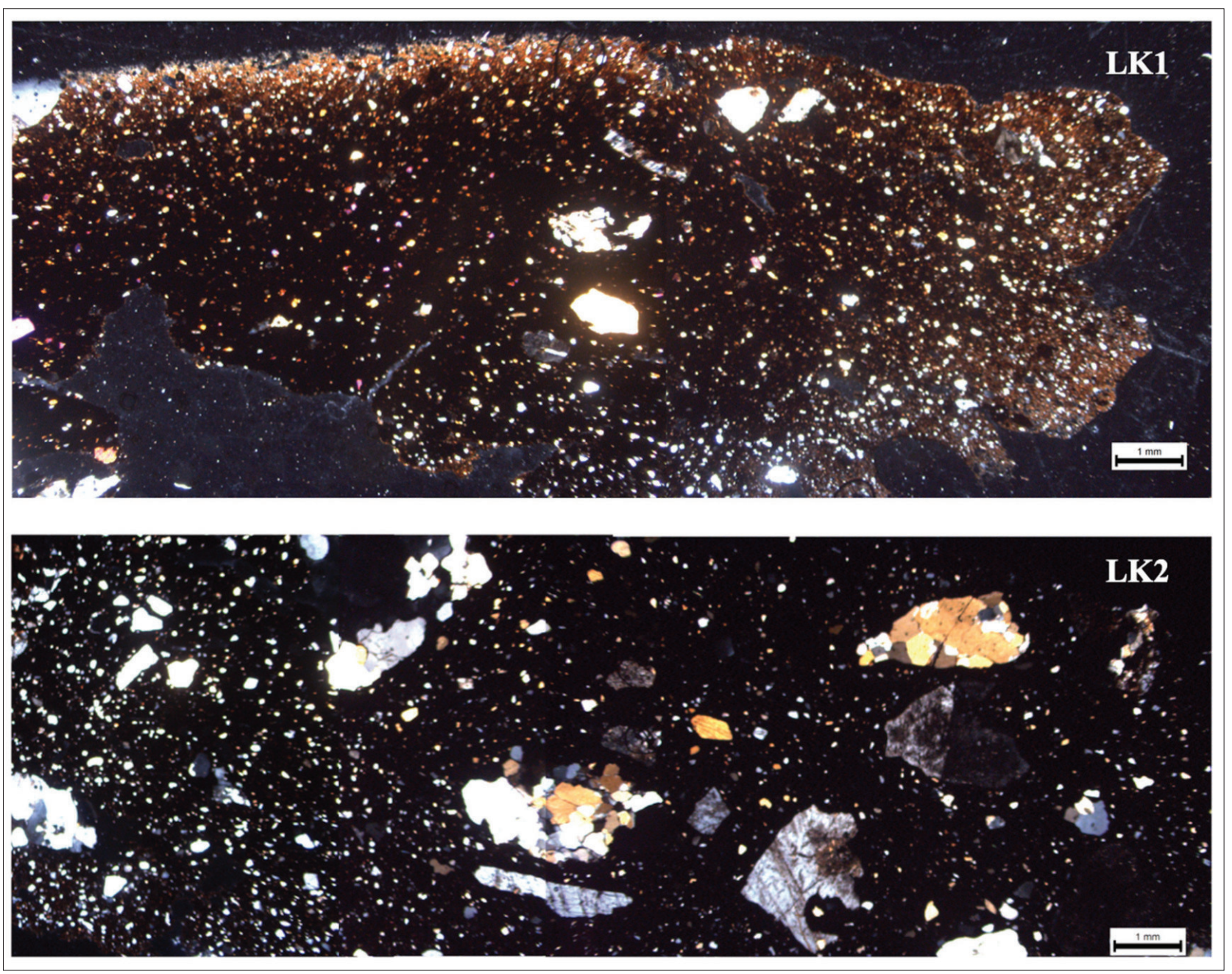

Figure 6. Micrographs of Laukskola pottery thin sections (XPL, created from several photographs attached,

prepared by V. Visocka).

vessels surviving from the settlement. However, the existence of these two types complies with the main production tendencies in the region (Visocka 2017b, pp. 60-61).

Size and wall thickness. Of the total number of 11 vessels, it was possible to determine the rim diameter of six. Only large vessels have been found in Laukskola; their rim diameter ranges from 18 to 28 centimetres, whereas the wall thickness is from 0.8 to 1.2 centimetres. The relation between the size and the wall thickness of the vessels correlates, i.e., the larger vessels have thicker walls (Fig. 9.A). The same correlation, with some exceptions, is seen in the hillfort material as well. Although the hillfort material has a larger variety of different-sized vessels, it is important to note that the Laukskola pots come from only one object, and therefore might not represent the true diversity of size. Although the wall thickness of the vessels ranks in the main tendencies, the grain size variations (macroscopic measurements) are more similar to the Kivutkalns and Vinakalns pottery (Fig. 9.B). Lastly, size corresponds to temper grain size as well, i.e., the bigger vessels have a coarser temper added (Fig. 9.C). Thus, large vessels overall have thicker walls and a coarser temper. This is a common practice in pre-wheel pottery, as thicker walls are needed in order to gain stability during the production of larger vessels (Rice 1987, p. 227). Unfortunately, it is not possible to determine the precise height of the vessels, so it is not possible to calculate their volume.

\section{Stylistics and morphology}

Surface treatment. The most common type of pottery in the east Baltic during the LBA was pottery with striated (or brushed) surface treatment. Thus, this type is considered to be a local tradition in the region. Smooth pottery is also common in the eastern part of Latvia (Brikuli hillfort); it is more preferred than applying striation (Vasks 1994, p. 49). Vessels with a textile and a coarse-slipped (or early rusticated) surface are far less common. The Laukskola settlement contained almost only striated pottery (99\%); only one vessel besides striation had a thin coarsegrained clay slip (Fig. 10.A). Although striated pottery is dominant in the Lower Daugava hillforts, there are 

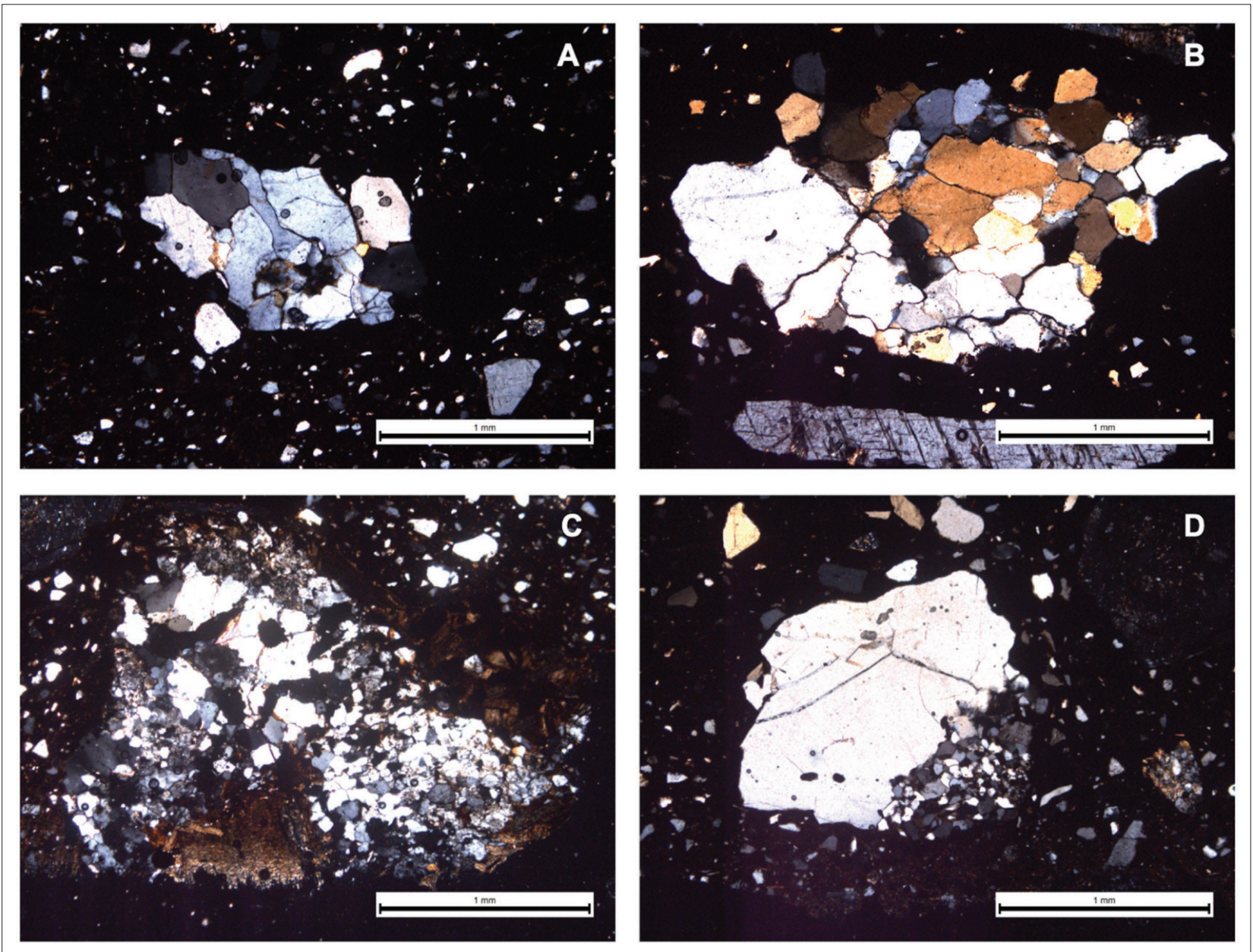

Figure 7. Micrographs of quartzite (A, B) and granitic rock (C, D) temper in the LK2 sample (XPL, prepared by V. Visocka).

varieties of other types as well. Notably, striated-coarseslipped pottery was also found in Kivutkalns and Vīnakalns, but at Klangíukalns only vessels with a striated and smooth surface (Visocka 2020, pp. 90-94). The vessels are mostly striated with tools with medium-rough bristles, some have rougher striation, possibly from a bundle of twigs. Most of the vessels have a horizontal roughly striated inner surface, which is also common in other settlements, including Lower Daugava hillforts (Vasks 1991, p. 41).

Ornamentation. Unlike in all other Lower Daugava settlements, most (six) of the reconstructed vessels had ornamented surfaces. The vessels were mostly ornamented with different kinds of pits, in one to at least five rows (Fig. 11). In one case, it was possible to distinguish motifs as well: after three rows of pits followed two rows, which made a pattern of triangles (Table 1 No. 11). It seems that the pits and the line impressions were made with different kinds of tools. It is known that pits are mostly made by using some kind of stamp from a wooden stick or bone (Cimermane 1976). In two cases (Table 1, Nos 2 and 6), the application and the material used to make the ornamentations are not clear.

Therefore, the authors conducted a small experiment (Fig. 12). By using RTI, models of the pottery surfaces were made, and positives of the ornamentation were taken by moulding clay (Fig. 12.A.1, 2; B.1, 2). The impression/incision ornamentation of the first vessel has small tooth-like snicks; the length of the largest impression is 5.91 millimetres. They are especially visible on one side, while the other is relatively straight. In the opinion of the authors, this ornamentation by its nature recalls a fishbone, more precisely, preopercles (Fig. 12.A. 4). Preopercles from two different individuals obtained from the excavations at Laukskola Iron Age settlement were used to replicate the impressions in the moulding clay. Bone was pressed into the moulding clay in a similar fashion (oblique direction) as in the original. The shortest and the longest sides of the bone were pressed in the clay. The resulting impressions of the shortest sides are quite similar to the ones on the pottery: one of the sides has snicks, while the other is relatively straight. It is notable that the sizes of the chosen bones (even the shortest side) are bigger than the 


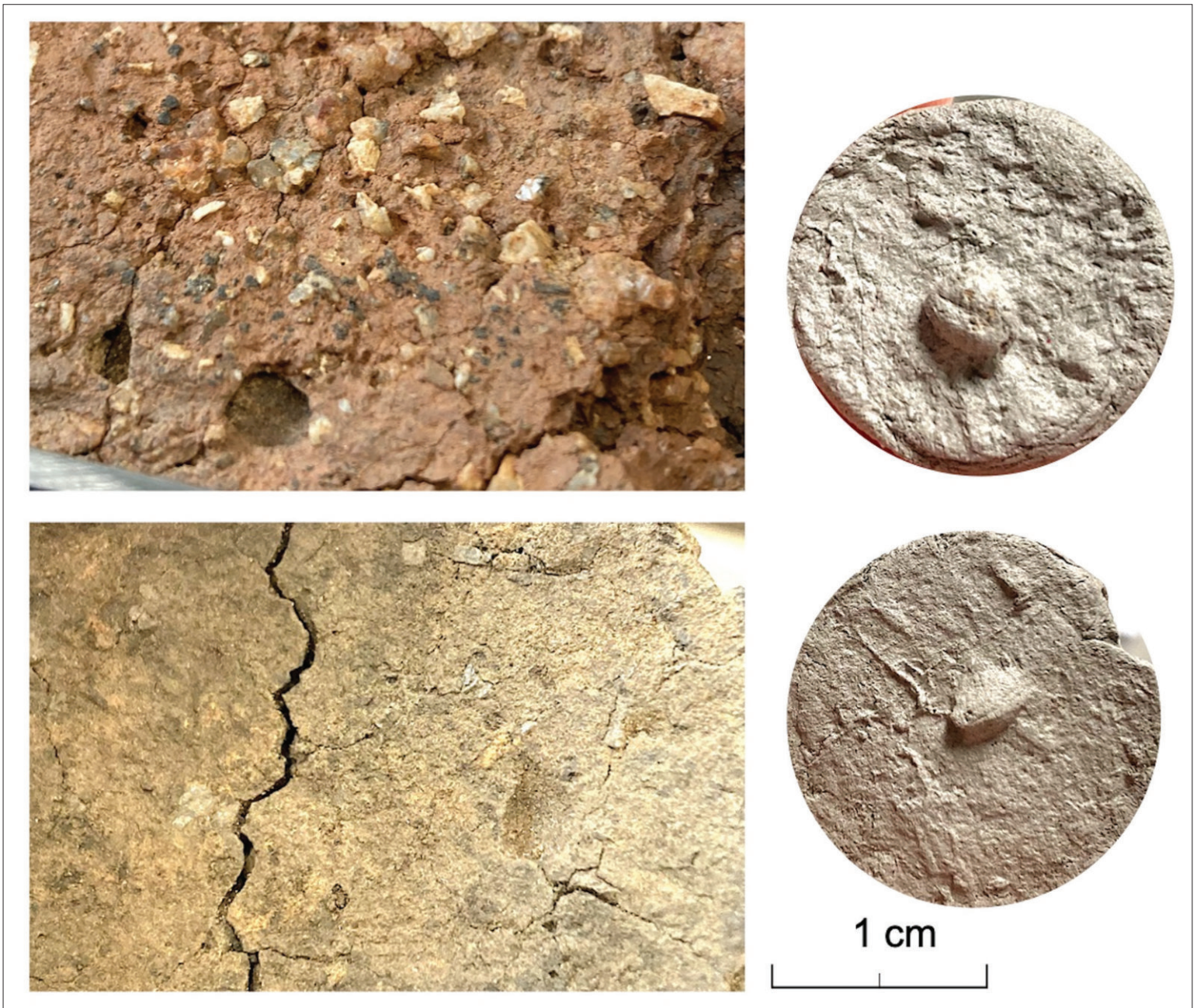

Figure 8. Imprints of seeds and their positives (photograph by V. Visocka).

ones actually used on the vessel. Thus, the snicks are wider than the ones in the original. However, the overall pattern is very similar, making the authors believe that fishbones with spiky edges like preopercle were probably used to decorate this vessel. Although the use of aquatic animal bones to decorate the surfaces of vessels has been noted in Neolithic settlements (Bērzinšs and Dumpe 2016), there are no known analogies regarding fishbone ornamentation in the east Baltic and nearby regions during the LBA.

The other vessel was decorated with oval elongated and uneven pits, of which the length reaches 14 millimetres. The positive of this pit, as well as the size and dimensions, reminded the authors of some kind of bird or small mammal bone (Fig. 12.B.2). Therefore, three kinds of bird (chicken) bones obtained from Daugmale hillfort (Iron Age) were chosen for the experiment: ulna, humerus and tarsometatarsus (Fig. 12. B. 3, u, h, t). The pit most similar to the original was created by using a humerus. Although the shape is similar, the additional three small pits created within the big one by using a humerus are not observed in the vessel. Thus, it is most likely that these types of bone were not used to decorate pottery.
Profile forms. Regarding the morphology of the vessels, it can be seen that Laukskola differs significantly from the other settlements in the area, as the dominant profile shape is slightly profiled (CS), and not barrel shaped (Fig. 10. B). Profiled rim shapes are more common during the LBA in sites in Courland, such as Padure and Krievu kalns hillforts (Vasks et al. 2011, p. 82; Vasks et al. 2020, p. 91).

\section{Use-wear patterns}

Traces of use-wear were distinguished on all the vessels. In one case (Table 1, No 5), traces of possibly an unfinished rivet hole were found, which indicates intended secondary usage. Soot was noted on most (seven) of the Laukskola vessels. It was either just traces of soot, or soot with additional food crust remains. Soot was mostly identified on the outer upper wall of the vessels, and food crust on the inner walls and bottom. Experiments (Bērziņš and Dumpe 2005) show that soot appears on the upper walls during heating or cooking in a hearth, because the fire does not directly touch the upper part of the pot, thus indicating 


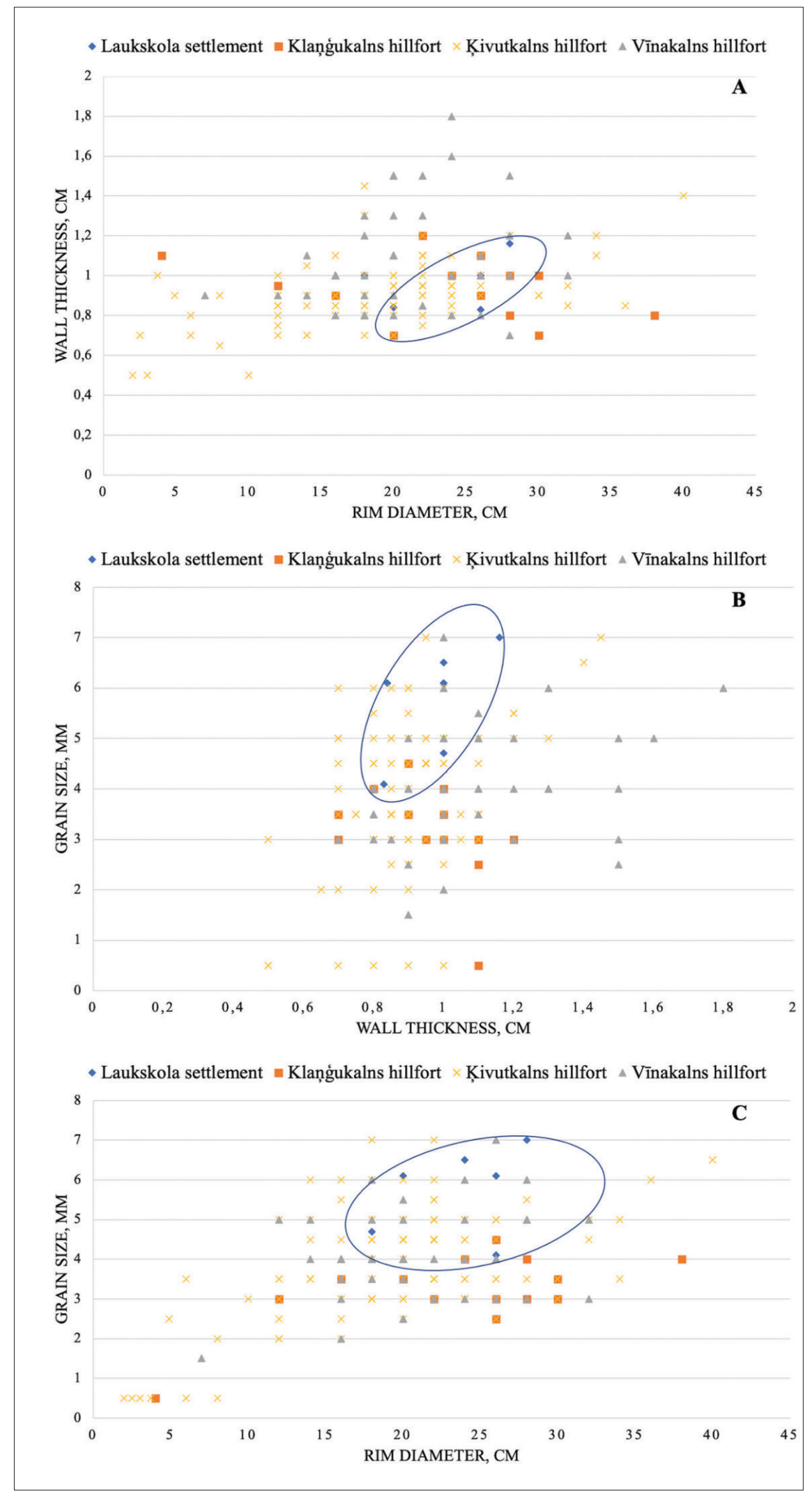

Figure 9. Scatterplots of different pottery production qualities: A. rim diameter and wall thickness ratio; B. temper size and wall thickness ratio; C. rim diameter and temper size ratio. 


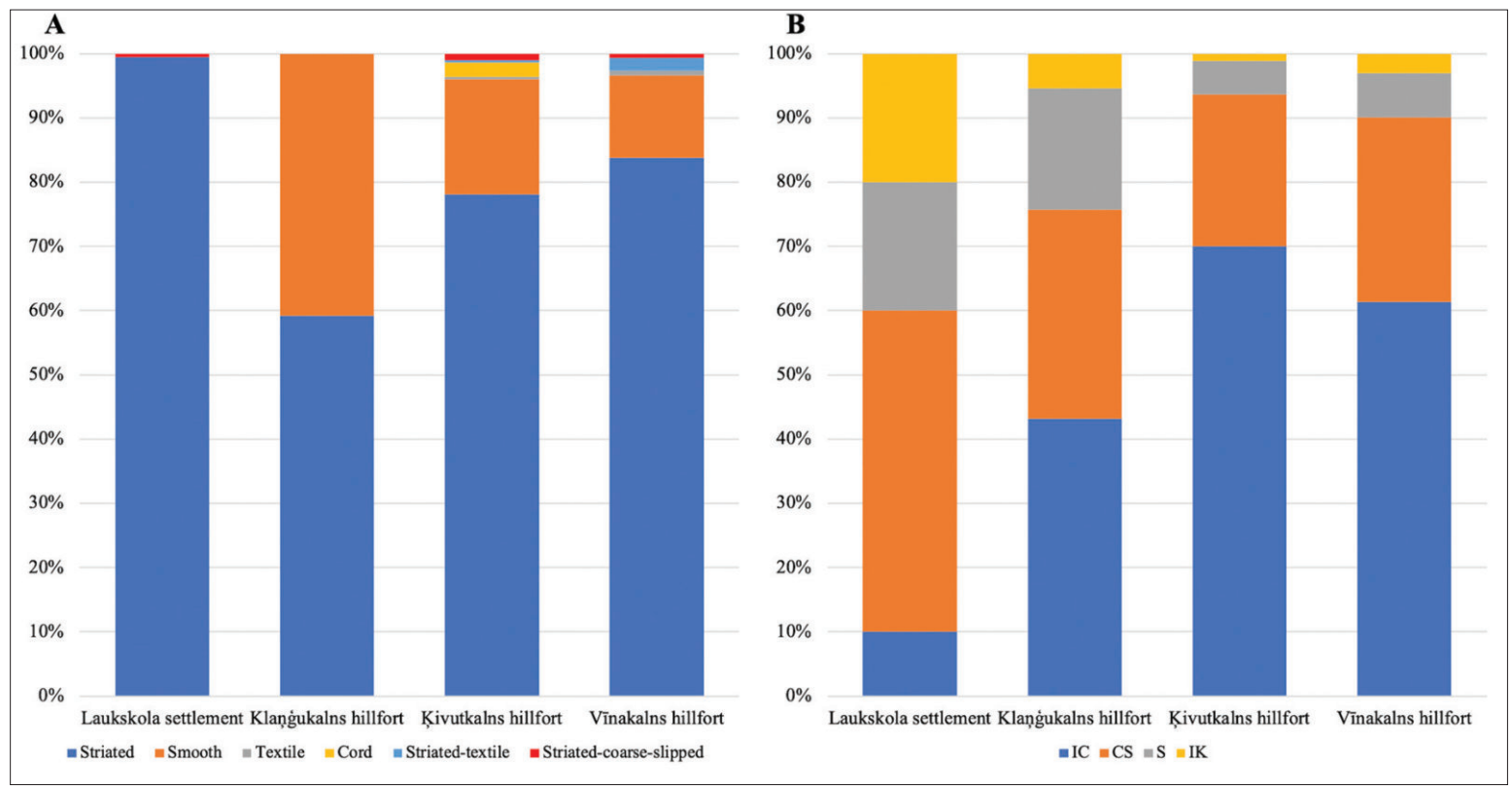

Figure 10. Graphs of percentages between different surface treatments (A) and profile shapes (B) in all the analysed sites.

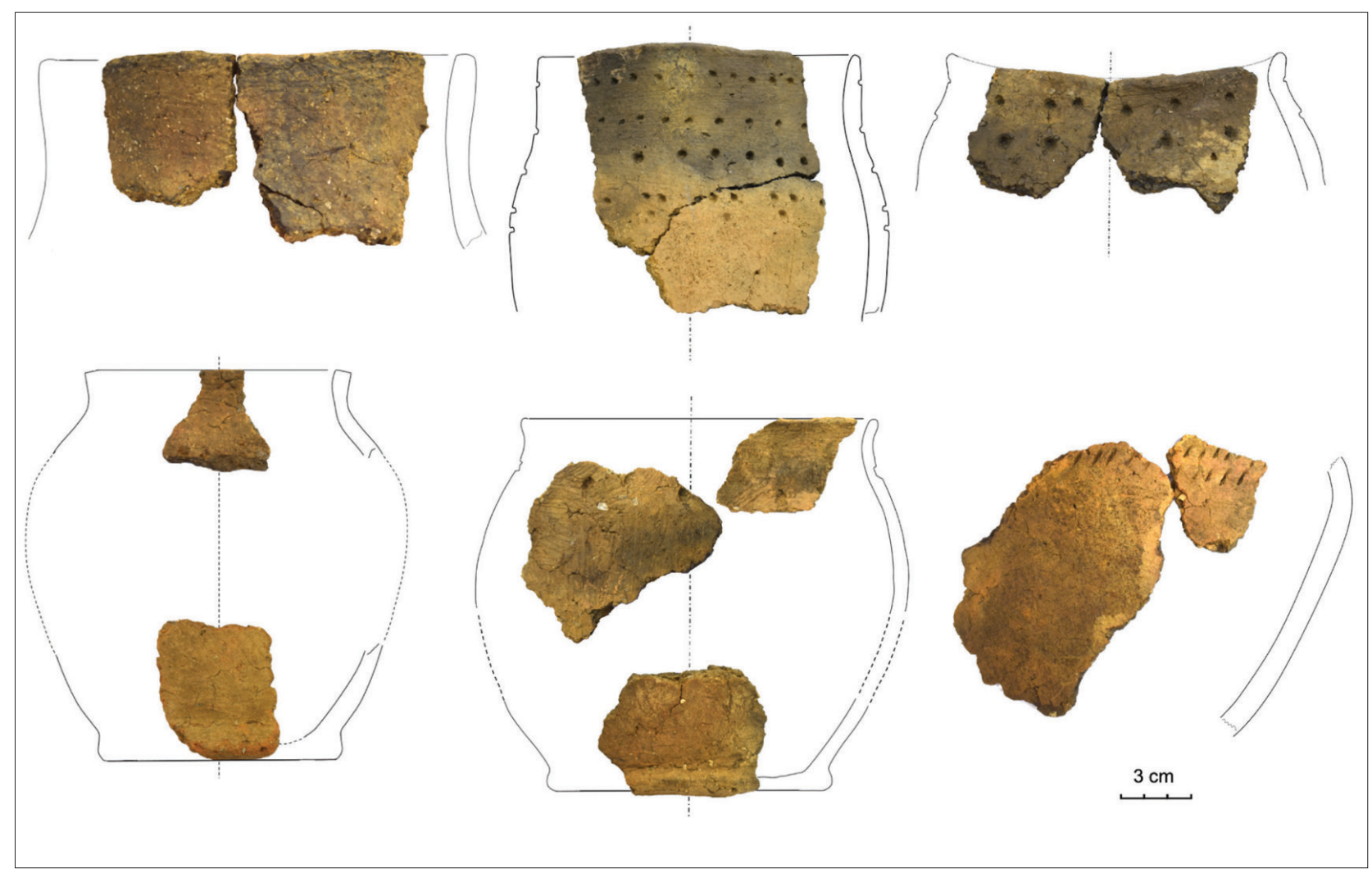

Figure 11. Reconstructed vessels from Laukskola (a selection, photograph by V. Visocka). 


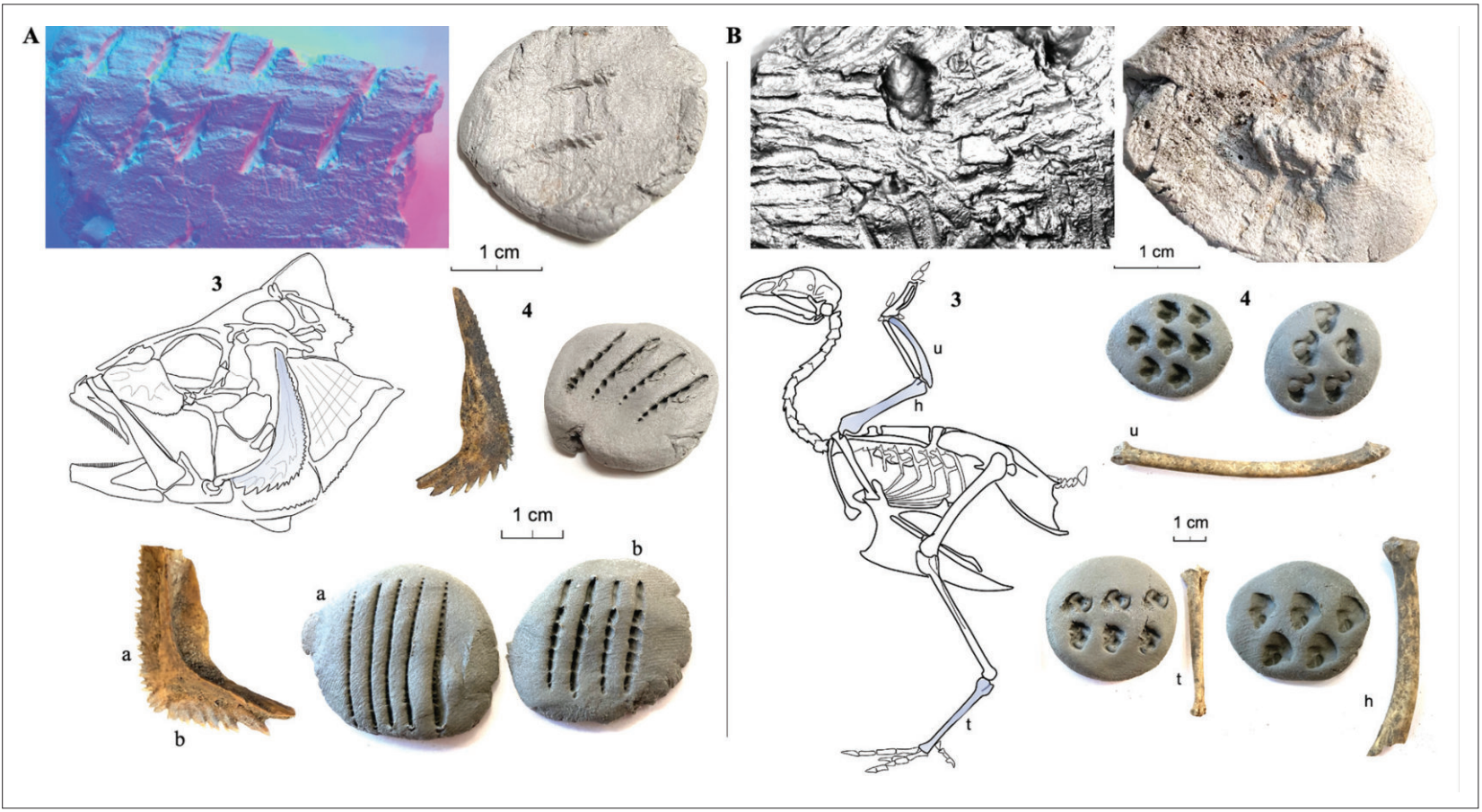

Figure 12. The visual results of the experiments. An experiment with fishbones: 1 . an RTI model of the vessel; 2. a clay positive of the ornamentation; 3. an illustration of the fish skull (after Francis. 1889, p. VII); 4. the results of the experiment. An experiment with chicken bones: 1 . an RTI model of the vessel; 2. a clay positive of the ornamentation; 3 . an illustration of the chicken skeleton (after Goldfinger 2004. p. 218); 4. the results of the experiment (RTI models, photograph, and illustrations by V. Visocka).

that the vessels found were actively used for heating or cooking purposes.

On the inner wall of the striated-coarse-slipped vessel, a circa 1.5-millimetre-thick layer of a dark substance was noted (Table 1, No. 1; Fig. 13). Based on the characteristics and some analogies (Pietrzak 2012, pp. 59-61), the authors concluded that the substance is (wood?) tar. It is notable that in the Vinakalns striated-coarse-slipped vessel, the remains of pine tar residue have been identified as well (Visocka 2017a, pp. 13-15). However, in the Vinakalns sample, there was no layer of tar, i.e., traces of it were absorbed in the walls, and detected by using lipid residue analysis.

Although there are no clear traces that indicated the production of tar at Laukskola and Vinakalns, this does not mean it was not produced. The use of tar in Europe, and thus its production, can be traced to the Neolithic (Rageot et al. 2019). Several systems for the production of wood tar can be distinguished: 1) allothermic, i.e., heating by using an external source; this system includes double-pot and pine tar production methods; 2) autothermic, i.e., generated heat sustains itself from the reaction created. This system consists of the tar dale method which is aceramic (Rageot et al. 2019, pp. 279-281). It is possible that one of the methods mentioned was used by prehistoric Lower Daugava communities; however, the Vinakalns and Laukskola sherds are too fragmentary to make fur- ther interpretations regarding tar production. Two other possibilities can be considered: 1) tar was simply stored in these vessels; 2) tar was used as a sealant to make the vessels more waterproof (Drieu et al. 2020, p. 304). This hypothesis would fit well with the common interpretation that coarse clay slip was applied to the surface of the vessels to make them more waterproof (Schiffer et al. 1994; Vasks 2001, p. 205).

Overall, the use-wear patterns show extensive use related to heating (maybe cooking) in a hearth. This is also indicated by how these pots were produced: from a coarse sandy clay paste with medium to coarse mineral tempering, thick walls, and a striated surface, all of which makes them well resistant to thermal shock (Santacreu 2014, p. 152; Schiffer et al. 1994, p. 209).

\section{Discussion and conclusions}

The results of the analysis show that the Laukskola pottery includes both local and seemingly non-local aspects in its production and stylistic tendencies. Although the Laukskola potters followed the striated pottery tradition, which is characteristic of the east Baltic, elements such as rich decoration and dominant curved profile shapes are not as common in the Lower Daugava (Vasks 1991, pp. 43-50). The only region where profiled vessel shapes were preferred is Courland, where a large number of decorated 


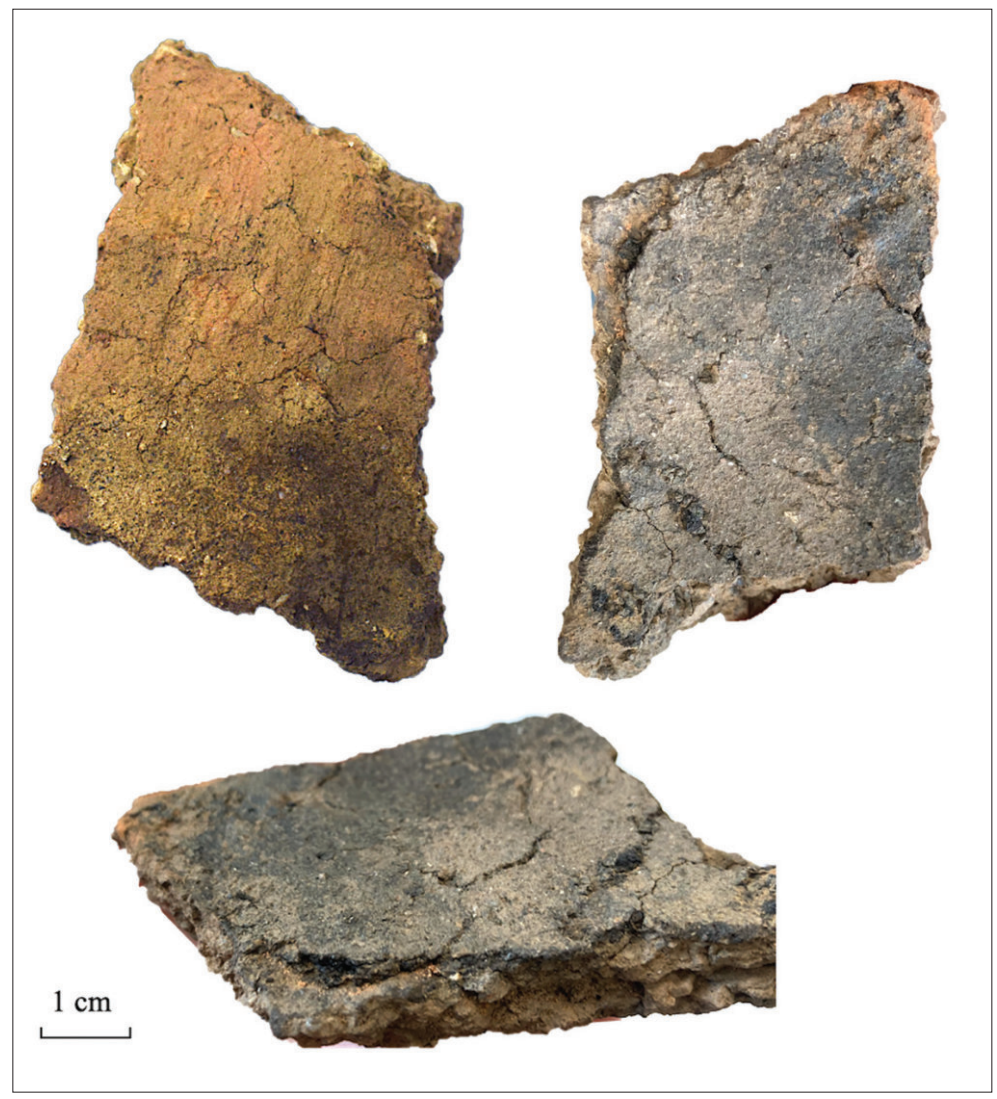

Figure 13. A striated-coarse-slipped vessel with a layer of tar (photograph by V Visocka).

vessels are found, at Brikuli (near Lake Lubāns, Latvia) and Asva (Saaremaa, Estonia) hillforts (Sperling 2014, pp. 239-242; Vasks 1982).

Fishbone ornamentation, which so far has no known analogies in the east Baltic, can be considered unique ornamentation. The only known ornamentation created using the bones of aquatic animals is from Neolithic sites, such as Sārnate, Pūrciems and Piestina, etc, where potters used porpoise teeth to decorate vessels (Bērziņš and Dumpe 2016). Most Neolithic sites with this ornamentation are located near the sea; therefore, the use of porpoise teeth to decorate vessels might have had a deeper meaning, maybe related to the relationship between food and pottery. It is known that fish and wild animals still played a prominent role in the diet of LBA communities. For example, at Kivutkalns, $8 \%$ of all bones were from fish, most of which were found abundantly in hearths. Wild animal bones, in turn, make up 6\% (Graudonis 1989, pp. 80-81). As the Laukskola settlement was located on the banks of the River Daugava, fishing most likely played a significant role in the diet. Thus, this decoration might have had a spiritual meaning: the importance of fish.

Chemical and petrographic analysis shows that the Laukskola pottery was made from local highly malleable moraine clay, like the pottery from Klanggukalns, Kivutkalns and Vinakalns. Just as in the nearby hillforts and LBA pottery in the east Baltic overall, clay was tempered with crushed granitic rock. However, in one case, quite an untypical temper was used: quartzite. So far, there are no known analogies of the use of this kind of temper. Quartzite is widely distributed in Latvia, mostly in the form of small boulders, and therefore is easily available, and is not imported from other regions (Sedmalis and Šperberga 2005, p. 62).

Finds of wheat imprints on pottery and use-wear patterns related to cooking or heating might indicate that Laukskola was a long-term settlement where farming was practised; however, additional data to support this hypothesis is missing. Object No 728 itself, based on the macroscopic pottery features and use-wear patterns, might have been a household pit, where hearth pots were kept while not being used. However, the information on the context is too sparse to draw any conclusions on the function of this object.

\section{Acknowledgements}

This study was funded by the State Culture Capital Foundation of Latvia, as part of the project 'The Determination of the Chronological Framework of Bronze and Pre- 


\section{APPENDICES}

Table 1. The data from the Laukskola vessels analysed.

\begin{tabular}{|c|c|c|c|c|c|c|c|c|c|c|}
\hline No. & Inv. No. & $\begin{array}{l}\text { Surface } \\
\text { treatment }\end{array}$ & $\begin{array}{l}\text { Pro- } \\
\text { file } \\
\text { shape }\end{array}$ & $\begin{array}{l}\text { Orna- } \\
\text { menta- } \\
\text { tion }\end{array}$ & $\begin{array}{l}\text { Rim } \\
\text { diam- } \\
\text { eter, } \\
\text { cm }\end{array}$ & $\begin{array}{l}\text { Wall } \\
\text { thick- } \\
\text { ness, cm }\end{array}$ & $\begin{array}{l}\text { Grain } \\
\text { size, } \\
\text { mm }\end{array}$ & $\begin{array}{l}\text { Use- } \\
\text { wear } \\
\text { pat- } \\
\text { terns }\end{array}$ & $\begin{array}{l}\text { Place- } \\
\text { ment of } \\
\text { use-wear }\end{array}$ & $\begin{array}{l}\text { Com- } \\
\text { ments }\end{array}$ \\
\hline 1. & LNVM VI 128:8626 & $\begin{array}{l}\text { Striated- } \\
\text { coarse- } \\
\text { slipped }\end{array}$ & $\mathrm{n}$ & $\mathrm{n}$ & $\mathrm{n}$ & 1.1 & 6.04 & $\begin{array}{l}\text { tar, } \\
\text { soot }\end{array}$ & $\begin{array}{l}\text { inner wall, } \\
\text { outer wall }\end{array}$ & \\
\hline 2. & LNVM VI 128:8626 & Striated & IK & $\begin{array}{l}\text { im- } \\
\text { pres- } \\
\text { sion }\end{array}$ & 26 & 0.83 & 4.1 & $\begin{array}{l}\text { soot, } \\
\text { crust }\end{array}$ & inner wall & $\begin{array}{l}\text { impres- } \\
\text { sion of } \\
\text { fish bone, } \\
\text { lenght - } \\
5.91 \mathrm{~mm} \text {, } \\
\text { thin sec- } \\
\text { tion LK1 } \\
\end{array}$ \\
\hline 3. & LNVM VI 128:8626 & Striated & IC & pits & $\mathrm{n}$ & 1.1 & 5.8 & crust & inner wall & $\begin{array}{l}\text { pit size - } \\
3.04 \mathrm{~mm}\end{array}$ \\
\hline 4. & LNVM VI 128:8626 & Striated & CS & $\mathrm{n}$ & 28 & 1.16 & 7 & soot & on rim & $\begin{array}{l}\text { seed } \\
\text { imprint } \\
\text { in paste, } \mathrm{n} \\
\text { building } \\
\text { technique }\end{array}$ \\
\hline 5. & LNVM VI 128:8626 & Striated & CS & $\mathrm{n}$ & 20 & 0.84 & 6.1 & crust & inner wall & \begin{tabular}{|l} 
seed \\
imprint, \\
possible \\
traces of \\
rivet hole
\end{tabular} \\
\hline 6. & LNVM VI 128:8626 & Striated & $S$ & pits & 26 & 1 & 6.1 & crust & $\begin{array}{l}\text { inner bot- } \\
\text { tom }\end{array}$ & $\begin{array}{l}\text { size of the } \\
\text { pits - } 14 \\
\text { mm }\end{array}$ \\
\hline 7. & LNVM VI 128:8626 & Striated & CS & $\mathrm{n}$ & $\mathrm{n}$ & 1.07 & 5.2 & soot & \begin{tabular}{|l} 
upper \\
outer and \\
inner wall \\
\end{tabular} & $\begin{array}{l}\text { u building } \\
\text { technique }\end{array}$ \\
\hline 8. & LNVM VI 128:8626 & Striated & CS & pits & 18 & 1 & 4.7 & soot & $\begin{array}{l}\text { outer up- } \\
\text { per wall }\end{array}$ & $\begin{array}{l}\text { snick im- } \\
\text { pression } \\
\text { made in a } \\
\text { pit, size 4 } \\
\mathrm{mm}\end{array}$ \\
\hline 9. & LNVM VI 128:8626 & Striated & IK & pits & $\mathrm{n}$ & 1 & 3 & soot & outer wall & $\begin{array}{l}\text { u building } \\
\text { technique }\end{array}$ \\
\hline 10. & LNVM VI 128:8626 & Striated & $S$ & $\mathrm{n}$ & $\mathrm{n}$ & 0.8 & 5.6 & crust & inner wall & \\
\hline 11. & LNVM VI 128:8626 & Striated & CS & pits & 24 & 1 & 6.5 & $\begin{array}{l}\text { soot, } \\
\text { crust }\end{array}$ & $\begin{array}{l}\text { outer and } \\
\text { inner } \\
\text { walls }\end{array}$ & $\begin{array}{l}\text { pits in } \\
\text { five rows, } \\
\text { creating } \\
\text { motif, size } \\
\text { of the pits } \\
5.59 \mathrm{~mm} \text {, } \\
\text { u building } \\
\text { technique }\end{array}$ \\
\hline
\end{tabular}


Table 2. The data from the clays analysed (XRF X-ray fluorescence spectrometry; CP ceramic petrography).

\begin{tabular}{|c|c|c|c|c|c|c|}
\hline Code & Location & $\begin{array}{l}\text { Munsell } \\
\text { colour (raw, } \\
\text { dry) }\end{array}$ & $\begin{array}{l}\text { Munsell } \\
\text { colour (fired } \\
\left.700^{\circ} \mathrm{C}\right)\end{array}$ & Characteristics & Workability & $\begin{array}{l}\text { Analysis con- } \\
\text { ducted }\end{array}$ \\
\hline DGM1 & $\begin{array}{l}\text { Daugmale hillfort } \\
\text { coastal slope }\end{array}$ & 10 YR $6 / 5$ & 7.5 YR $6 / 6$ & Silty, soily, plastic & Good & XRF, CP \\
\hline DGM2 & $\begin{array}{l}\text { In ploughed land } \\
\text { near Daugmale } \\
\text { hillfort }\end{array}$ & 7.5 YR 5/4 & 7.5 YR $5 / 8$ & Sandy, sticky, plastic & Very good & XRF, CP \\
\hline DZI1 & \multirow{2}{*}{$\begin{array}{l}\text { Steep bank of } \\
\text { the Daugava at } \\
\text { Dzintari }\end{array}$} & 7.5 YR $5 / 6$ & 5 YR $5 / 8$ & $\begin{array}{l}\text { Plastic, sandy and mi- } \\
\text { caceous }\end{array}$ & Good & XRF \\
\hline DZI2 & & 7.5 YR $6 / 3$ & 7.5 YR 6/6 & Very sandy, calcerous & Medium & XRF, CP \\
\hline NAS1 & $\begin{array}{l}\text { Bank of the Dau- } \\
\text { gava facing the } \\
\text { island of Nāvessala }\end{array}$ & 7.5 YR 5/6 & 7.5 YR $6 / 8$ & $\begin{array}{l}\text { Sandy, plastic, some } \\
\text { large dolomite inclu- } \\
\text { sions (sorted out) }\end{array}$ & Good & XRF \\
\hline SAL2 & $\begin{array}{l}\text { Bank of the } \\
\text { Daugava near the } \\
\text { monument of Ako }\end{array}$ & 10.5 YR $5 / 3$ & 7.5 YR 6/6 & $\begin{array}{l}\text { Sandy, plastic, some } \\
\text { large dolomite inclu- } \\
\text { sions (sorted out) }\end{array}$ & Good & XRF \\
\hline SLD1 & \multirow{2}{*}{$\begin{array}{l}\text { Near the village of } \\
\text { Saulesdārzs }\end{array}$} & 7.5 YR 5/5 & 7.5 YR 5/6 & Very sandy, plastic & Good & $\mathrm{XRF}$ \\
\hline SLD2 & & 7.5 YR 5/6 & 5 YR $5 / 8$ & Sandy, very plastic & Very good & XRF, CP \\
\hline SLKL1 & $\begin{array}{l}\text { Bank of the Dau- } \\
\text { gava near the vil- } \\
\text { lage of Saulkalne }\end{array}$ & 7.5 YR 6/2 & 10 YR $8 / 3$ & $\begin{array}{l}\text { Purified by the Dau- } \\
\text { gava, sticky, plastic }\end{array}$ & Good & XRF \\
\hline SRS1 & $\begin{array}{l}\text { Saurieši gypsum } \\
\text { quarry }\end{array}$ & $2.5 \mathrm{Y} 7 / 1$ & $10 \mathrm{YR} 7 / 4$ & $\begin{array}{l}\text { Plastic, large amount of } \\
\text { gypsum impurities }\end{array}$ & Not suitable & XRF, CP \\
\hline
\end{tabular}


ชู่

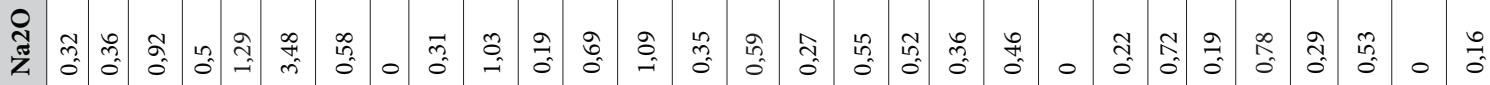

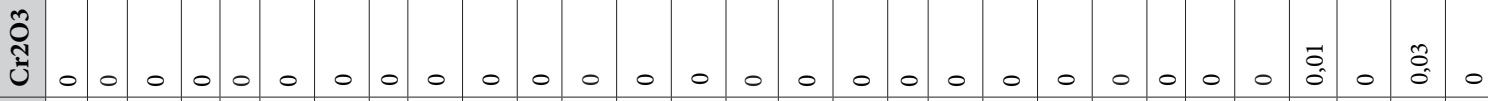
若

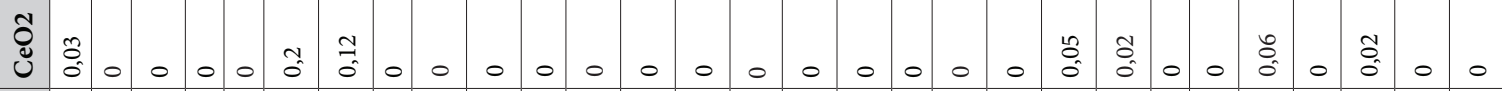

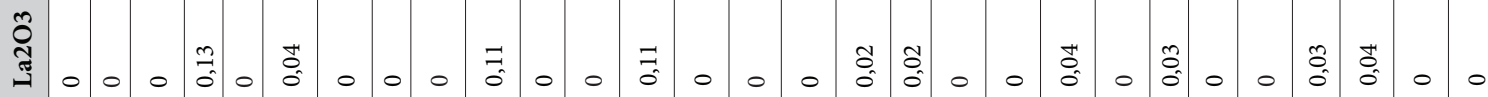

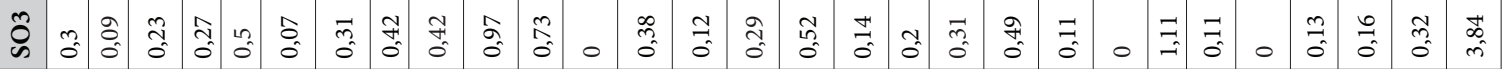

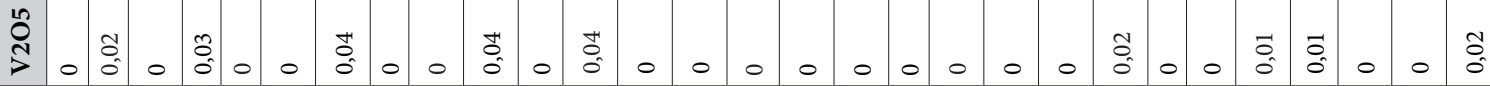

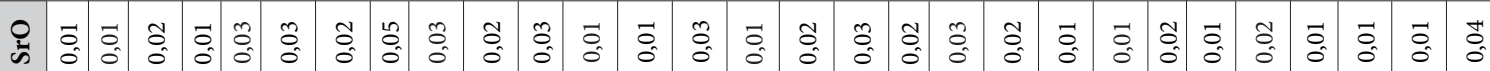

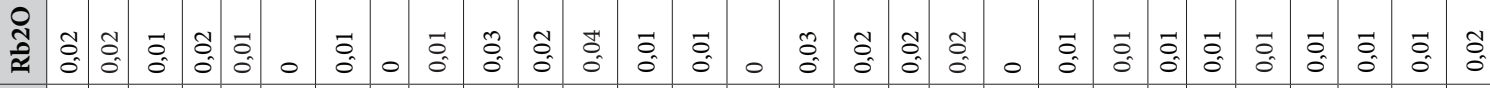

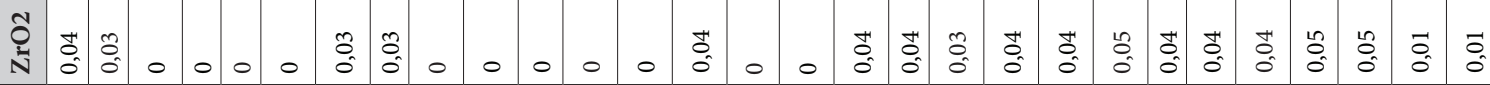

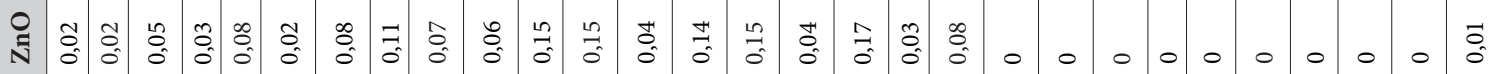

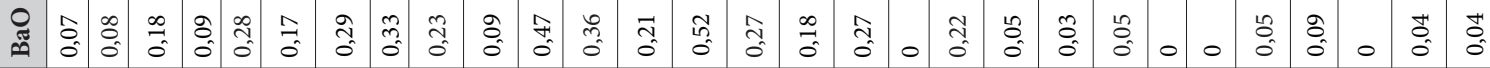

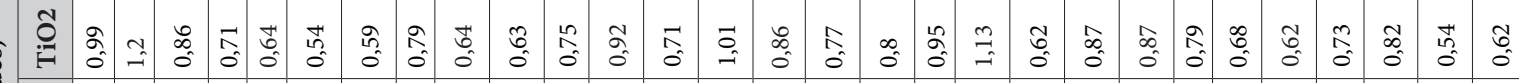

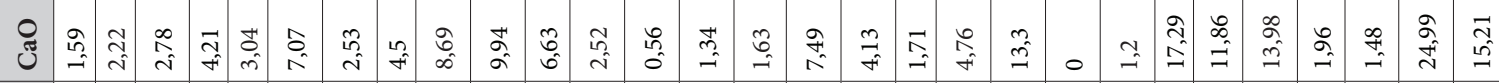

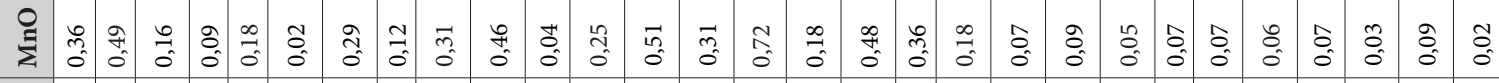

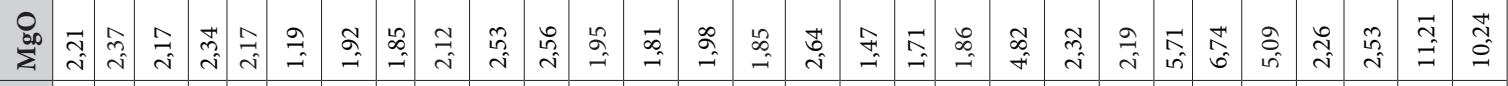

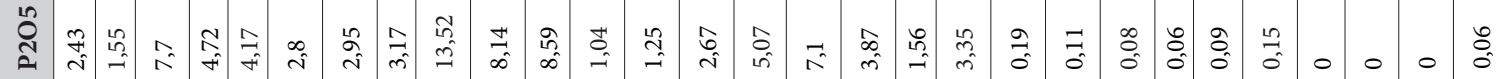

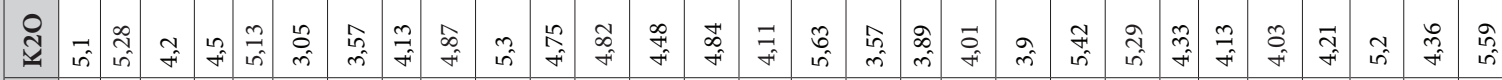

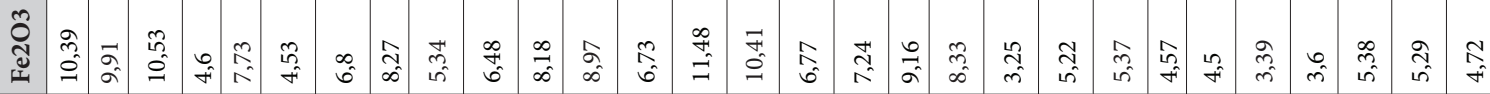

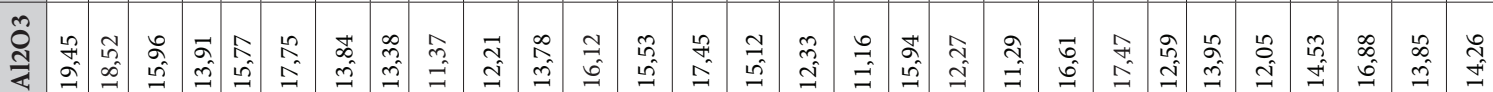

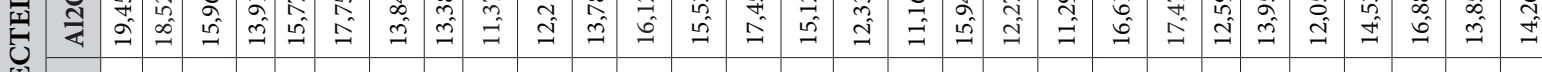

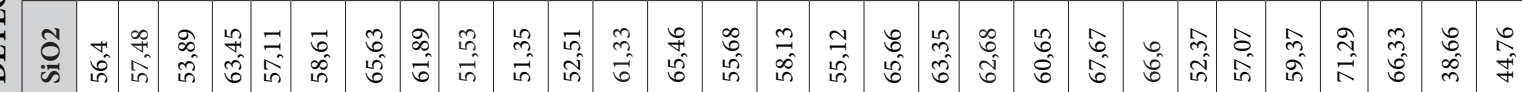

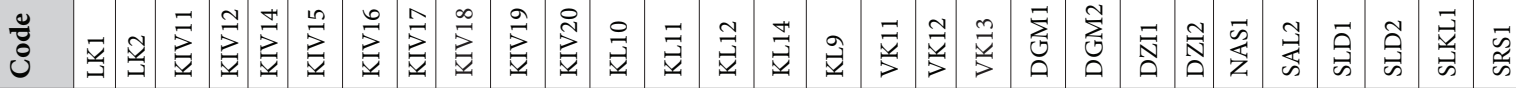

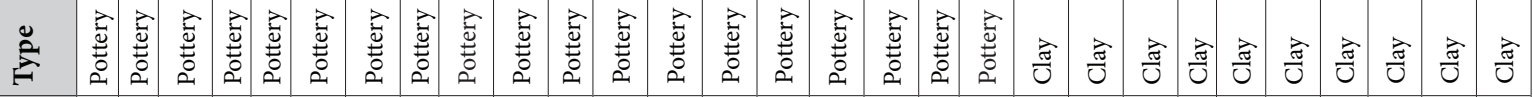

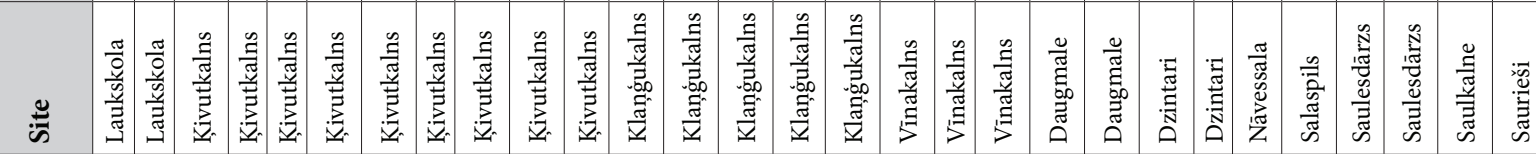

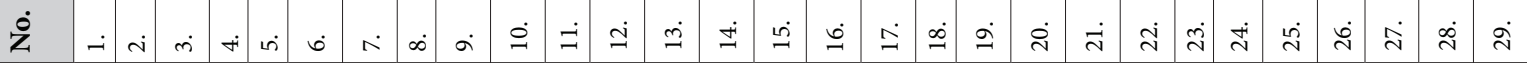


Roman Iron Age Striated Pottery by Using 14C AMS Dating' (2020-3KMA161). The authors are grateful to the archaeologist Andrejs Vasks, the chemist Artis Kons, and the palaeobotanist Aija Cerina for their advice.

\section{Abbreviations}

Archaeol. Baltica - Archaeologia Baltica

ZASM - Zinātniskās atskaites sesijas materiāli par arheologu, antropologu un etnogrāfu darbu ... gada pētījumu rezultātiem. Rīga: Zinātne

\section{References}

\section{Manuscripts}

Skrastinsh, K., 1948. Otchet o razvedke Dolessalskogo mestorozhdenjija mergeljei (kafelnjih gljini). Inv. No. 84. Stored at Latvian Environment, Geology and Meteorology Centre Geological fund (LVGMC GF).

Zariņa, A., 1970b. Salaspils Laukskolas 1970. g. izrakumu pārskats. Stored at University of Latvia Institute of Latvian History Repository of Archaeological material (LU LVI AMK), Inv. No. AA 232 and National History Museum of Latvia Department of archaeology (LNVM AD), Inv. No. AA 753.

Zarina, A. 1975b. Salaspils Laukskolas 1975. g. izrakumu pārskats. Stored at LU LVI AMK, Inv. No. AA 335 and LNVM AD, Inv. No. AA 758

\section{Literature}

Andrade, F., A., Al-Qureshi, H., A., Hotza, D., 2011. Measuring the plasticity of clays: A review. Applied Clay Science, 51, 1-7.

Bērziņš̌, V., Dumpe, B., 2005. Ėdiena eksperimentāla gatavošana, lietojot neolīta laika māla trauku rekonstrukcijas. Latvijas Vēstures institūta žurnāls, 1 (54), 5-22.

Bērziņš, V., Dumpe, B., 2016. Cūkdelfīnu zobu iespiedumi neolìta keramikas rotājumā. Latvijas Vēstures institūta žurnāls, 1 (98), 5-27.

Cimermane, I., 1976. Māla trauku ornamentu veidi Latvijā m.ē. I gadu tūkstotī. In: ZASM par arheologu un etnogräfu 1975. gada pētījumu rezultātiem. Rīga: Zinātne pp. 33-39.

Drieu, L., Lepère, C., Regert, M., 2020. The Missing Step of Pottery chaîne opératoire: Considering Post-firing Treatments on Ceramic Vessels Using Macro- and Microscopic Observation and Molecular Analysis. Journal of Archaeological Method and Theory, 27, 302-326. DOI: https://doi.org/10.1007/s10816019-09428-8.

Dumpe, B., Stunda-Zujeva, A., Vecstaudža, J., 2016. Pottery Firing without a Kiln - Hand Built Pottery in the Territory of Present-Day Latvia in the Middle and Late Iron Age (5th-12th centuries AD. In: P. E. Pettersson, ed. Prehistoric Pottery Across the Baltic: Regions, Influences and Methods. In: BAR International Series 2785. Oxford: British Archaeological Reports Oxford Ltd, pp. 43-53.

Eiduks, J., 1961. Latvijas PSR derīgie izrakteņi un to izmantošana. Rīga: Latvijas valsts izdevniecība.

Eriksson, T., Lindahl, A., 2012. The Handicrafts of Iron Age Pottery in Scandinavia: Regionalities and Traditions. Lund Archaeological Review, 18 (2012), 45-60.
Francis D., 1889. The fauna of British India including Ceylon and Burma. Fishes, Vol. 1. London: Taylor and Francis.

Goldfinger, F., 2004. Animal anatomy for artists. Oxford: Oxford University press, p. 218

Graudonis, J., 1989. Nocietinātās apmetnes Daugavas lejtecēe. Rìga: Zinātne.

Hall, M., E., 2016. X-ray Fluorescence Energy Dispersive (ED$\mathrm{XRF}$ ) and Wavelength Dispersive (WD-XRF) Spectrometry. In: A.M.W. Hunt, ed. The Oxford Handbook of Archaeological Ceramic Analysis. Oxford: Oxford University Press, pp. 342-362.

DOI: 10.1093/oxfordhb/9780199681532.001.0001.

Kuršs, V., Stinkule, A. 1972. Māli Latvijas zemes dzìlēs un rūpniecībā. Rīga: Liesma.

Mudge, M., Lum, M., Schroer, C., Malzbender, T., 2013. Reflectance Transformation Imaging: Guide to Highlight Image Capture, v2.0. Cultural Heritage Imaging, 1-32. Available from: http://culturalheritageimaging.org/What We Offer/Downloads/Capture/index.html.

Pietrzak, S., 2012. Wood Tar in the Dnieper and Elbe Communities: VI - II millenium BC. Poznań: Zakłady Poligraficzne TMDRUK.

Quinn, P., S., 2013. Ceramic petrography: The interpretation of archaeological pottery and related artefacts in thin section. Oxford: Archaeopress.

Rageot, M., Théry-Parisot, I., Beyries, S., Lepère, C., Carré, A., Mazuy, A., Filippi, J-J., Fernandez, X., Binder, D., Regert, M., 2019. Birch Bark Tar Production: Experimental and Biomolecular Approaches to the Study of a Common and Widely Used Prehistoric Adhesive. Journal of Archaeological Method and Theory, 26, 276-312.

DOI: https://doi.org/10.1007/s10816-018-9372-4.

Rasiņš, A., Tauriņa, M., 1983. Pārskats par Latvijas PSR Arheologiskajos izrakumos konstatētajām kultūraugu un nezālu sēklām. Arheologiija un Etnogrāfija, XIV, 152-176.

Rice, P.M., 1987. Pottery Analysis: A Sourcebook. Chicago - London: The University of Chicago Press.

Santacreu, D., A. 2014. Materiality, Techniques and Society in Pottery production: the technological study of archaeological ceramics through paste analysis. Warsaw-Berlin: De Gruyter Open. DOI: https://doi.org/10.2478/9783110410204.

Schiffer, M., B., Skibo, J., M., Boelke, T., C., Neupert, M.A., Aronson, M., 1994. New perspectives on experimental archaeology: Surface treatments and thermal response of the clay cooking pot. American Antiquity, 59, 197-217.

Sedmalis, U., Šperberga, I., 2005. Mineralogíja. Rīga: RTU izdevniecība.

Sperling, U., 2014. Aspekte des Wandels in der Bronzezeit im Ostbaltikum. Die Siedlungen der Asva-Gruppe in Estland. Tallinn: Estonian Academy Publishers.

Šnore, R., 1936. Izrakumi Doles pag. Klanğgu pilskalnā. Senatne un Māksla, 1, 57-69.

Šulte, A., Gunnarsson, D.S.E., 2017. Ieskats Salaspils Laukskolas apmetnes un kapulauka keramikas telpiskajā analīzē. In: Latvijas nacionālā vēstures muzeja raksti, 23. Rīga: Jelgavas tipogrāfija, pp. 11-19.

Vasks, A. 1982. Ranniy kompleks keramiki ukreplennogo poseleniya Brikuli. Latvijas Zinātñu Akadēmijas Vēstis, 9 (422), 57-67.

Vasks, A., 1991. Keramika epokhi pozdnjei bronzi i rannego zheleza Latvii. Riga: Zinatne.

Vasks, A., 1994. Brikulu nocietinātā apmetne: Lubāna zemiene vēlajā bronzas un dzelzs laikmetā (1000. g. pr. Kr.-1000. g. pēc $K r$.). Riga: Preses nams.

Vasks, A., 2001. Agrais dzelzs laikmets 1.-400. g. In: J. Graudonis, Ē. Mugurēvičs, A. Vasks. Latvijas senākā vēsture 9. g. 
t. pr. Kr. - 1200. g. Rīga: Latvijas vēstures institūta apgāds, pp. $186-231$.

Vasks, A., 2021. Laukskolas apmetne. In: G. Zarina, A. Vasks, ed. Latvijas arheoloğijas rokasgrāmata. Rīga: Zinātne, pp. 122-124.

Vasks, A., Kalnina, L., Daugnora, L., 2011. Beltu pilskalns. Arheoloǵija un Etnogräfija, XXV, 73-99.

Vasks, A., Visocka, V., Daugnora, L., Ceriņa, A., Laimdota, K., 2020. Krievu kalns Hill-Fort: New Data on the Late Bronze Age and Pre-Roman Iron Age in Western Latvia. Archaeol. Baltica, 26, 80-107. DOI: https://doi.org/10.15181/ab.v26i0.2024.

Vasks, A., Zarina, G., 2014. K,ivutkalna pilskalns un kapulauks: jauni dati un jaunas problēmas. Latvijas Vēstures Institūta žurnāls, 3 (92), 5-36.

Visocka, V., 2017a. Švīkāts-apmests trauks Vinnakalna pilskalna keramikas kolekcijā. Latvijas Vēstures institūta žurnāls, 4 (105), 5-24.

Visocka, V., 2017b. Pottery and Hillforts: Some Aspects of Pottery Production During the Late Bronze Age in the Territory of Latvia. Latvijas Universitātes žurnāls, 4 (99), 53-65.

DOI: http://doi.org/10.22364/luzv.

Visocka, V., 2020. Late Bronze and Pre-Roman Iron Age pottery in the Lower reaches of river Daugava. In: M. Marila, M. Ahola, K. Mannermaa, M. Lavento, eds. Interarchaeologia 6, Archaeology and Analogy. Papers from the Eight Theoretical Seminar of the Baltic Archaeologists (BASE), helt at the University of Helsinki and Tvärminne Zoological Station, Hanko, Finland, 30th November - 2nd December 2017. Hanko: University of Helsinki, pp. 83-104.

Visocka, V., Kalniņš, M., Kons, A., 2021. Resursu apzināšana arheolog̣ijas kontekstā: Māli Daugavas lejtecē, Kurzemē un Burtnieka ezera apkārtnē. In: A. Vilcāne, ed. Latvijas Universitātes 79. starptautiskās zinätniskās konferences sekcija "Arheologu un etnogrāfu pētījumi Latvijā 2018.-2020. gadā", 11th March 2021. Riga. University of Latvia, pp. 12-13.

Visocka, V., Podenas, V., Sperling, U. (in print), From the Seaside to the Inland: Comparing Late Bronze Age pottery production and styles in the eastern Baltic. In: D. Hofmann, R. Schumann, F. Nikulka, eds. The Baltic in the Bronze Age - regional patterns, interactions and boundaries. Leiden: Sidestone Press.

Zagorska, I., 1994. Salaspils Laukskolas akmens laikmeta apmetne. Arheologiija un Etnogräfija, XVI, 14-28.

Zagorska, I., 2012. Senie Ziemeḷbriežu mednieki Latvijā. Rīga: Zinātne.

Zariņa, A., 1968. 1967. g. arheoloǵiskie izrakumi Salaspils Laukskolā. In: ZASM par arheologu un etnogrāfu 1967. gada pètījumu rezultātiem. Rīga: Zinātne, pp. 80-82.

Zarina, A., 1969. Salaspils Laukskolas arheoloğiskās ekspedīcijas darbs 1968. g. In: ZASM par arheologu un etnogräfu 1968. gada pètījumu rezultātiem. Rīga: Zinātne, pp. 59-62.

Zariņa, A., 1970a. Arheolog̣iskie izrakumi Salaspils Laukskolā 1969. gadā. In: ZASM par arheologu un etnogrāfu 1969. gada pètījumu rezultātiem. Rīga: Zinātne, pp. 73-76.

Zarina, A., 1971. Arheologiskie izrakumi Salaspils Laukskolā 1970. gadā. In: ZASM par arheologu un etnogrāfu 1970. gada pētījumu rezultātiem. Rīga: Zinātne, pp. 65-67.

Zariņa, A., 1972. Arheoloǵiskie izrakumi Salaspils Laukskolā 1971. gadā. In: ZASM par arheologu un etnogrāfu 1971. gada pètījumu rezultātiem. Rīga: Zinātne, pp. 108-110.

Zariṇa, A., 1973. Izrakumi Salaspils Laukskolā 1972. gadā. ZASM par arheologu un etnogräfu 1972. gada pētījumu rezultātiem. Rīga: Zinātne, pp. 76-80.

Zariņa, A., 1974. Izrakumi Salaspils Laukskolā 1973. gadā. In: ZASM par arheologu un etnogräfu 1973. gada pētījumu rezultātiem. Rīga: Zinātne, pp. 87-90.
Zariņa, A., 1975a. Izrakumi Salaspils Laukskolā 1974. gadā. In: ZASM par arheologu un etnogrāfu 1974. gada pētījumu rezultātiem. Rīga: Zinātne, pp. 101-106.

Zariṇa, A., 1976. Izrakumi Salaspils Laukskolā 1975. gadā. In: ZASM par arheologu un etnogrāfu 1975. gada pētījumu rezultātiem. Rīga: Zinātne, pp. 100-104.

Zarina, A., 2006. Salaspils Laukskolas kapulauks 10.-13. gadsimts. Rīga: Latvijas Vēstures Institūta apgāds.

\section{TARP GALINGŲ PILIAKALNIŲ: \\ TARPDISCIPLININIS \\ LAUKSKOLOS BRONZOS \\ AMŽIAUS GYVENVIETÉS \\ KERAMIKOS TYRIMAS}

\section{VANDA VISOCKA, ALISE GUNNARSSONE, MĀRCIS KALNIN̦Š, EDUARDS PLANKĀJS}

\section{Santrauka}

Šis straipsnis skirtas Laukskolos vèlyvojo bronzos amžiaus (santrumpa: LBA) neitvirtintos gyvenvietes keramikos analizei. Laukskola LBA gyvenvietẻ buvo Dauguvos žemupyje, dešiniajame upès krante, netoli Doles salos, priešais Daugmalès piliakalnị (1 pav.). Remiantis 14C AMS analize, gyvenviete buvo apgyvendinta LBA (vèlyvasis bronzos amžius) pabaigoje (791-544 cal BC), tai atitinka netoliese esančių piliakalnių chronologiją. Kitaip tariant, Laukskolos gyvenviete ir aplinkiniai paminklai egzistavo kartu. Tyrimo tikslas - apibūdinti Laukskolos keramikos technologinius ir stilistinius aspektus bei atsekti jų ryši su Daugmalès piliakalnio medžiaga. Tikslui pasiekti buvo taikomi keli metodai - makroskopinè analizè, fotogrametrija (atspindinti ir vaizduojanti transformacijas), keramikos petrografija taikant padidintų keramikos pjūvių metodą ir bangos ilgio dispersinès rentgeno fluorescencijos (WD-XRF) spektrometriją. Be to, buvo atlikti kai kurie eksperimentai dèl ornamentikos ypatumų, atsirandančiu ornamentuojant indų paviršius (5-7 pav.).

Rezultatai rodo, kad „Laukskolos“ tipo keramika buvo gaminama vietoje, naudojant smèlio turtingą moreninị molį. Daugelio indų molio masè liesinta vidutinio smulkumo trintu granitu, kaip ir netoliese esančio piliakalnio keramikoje (8 pav.). Tačiau vieno indo molis buvo liesintas kvarcitu, kuris, nors ir plačiai prieinamas vietoje, yra netipiškas molio masei liesinti. Iki šiol nèra žinoma molio liesinimo kvarcitu analogijų. Tačiau visgi bendros Laukskolos molio masès keramikos paruošimo lipdyti tendencijos atitinka Klaņgukalnio, Kivutkalnio ir Vīnakalnio tendencijas. Remiantis indų savybèmis, buvo galima rekonstruoti 11 puodų. Visi indai yra neryškiai brūkšniuotu paviršiumi, t. y. pagaminti pagal vietines tradicijas (11 pav.). Tačiau 
buvo pastebèta kai kurių iš pažiūros nevietinių elementų, susijusių su jų stilistika ir morfologija, pavyzdžiui, dominuoja lenktos ir profiliuotos formos puodai, o dauguma (šeši) puodų yra su ornamentuotais paviršiais (11 pav.). Kuršo LBA piliakalniuose dominuoja profiliuoti indai, o artimiausios gyvenvietès, kuriose yra daug ornamentuotų indų, yra Brikul̦ių ir Asvos piliakalniai. Unikaliu ornamentu galima laikyti žuvies kaulais molio masejje įrěžtus motyvus (12:A pav.). Kol kas nèra žinoma analogijų su šia specifine ornamentika. Tačiau yra žinoma įspaudų, padarytų vandens paukščių kaulais (12:B pav.). Tokių žinoma neolito gyvenvietėse, esančiose netoli pajūrio ir Lubano ežero apyežerẻje. Visi „Laukskolos“ tipo indai greičiausiai buvo naudojami kaip virimo indai ir (arba) ne maistui šildyti dèl jų dydžio ir suodžių bei maisto plutos likučių ant vidinių ir išorinių indų sienelių (13 pav.). 